\title{
La prueba del Derecho extranjero ante los tribunales españoles
}

\author{
Alfonso-Luis Calvo Caravaca \\ Catedrático de Derecho internacional privado \\ (Universidad Carlos III de Madrid, España) \\ $\mathrm{y}$ \\ Javier Carrascosa González \\ Profesor titular de Derecho internacional privado \\ (Universidad de Murcia, España)
}

\begin{abstract}
Resumen: El cambio de escenario social del Derecho internacional, el correlativo y espectacular desarrollo del Derecho internacional privado (que ha pasado a ser, gracias fundamentalmente al impulso del Derecho comunitario, uno de los sectores con mayor dinamismo del Ordenamiento Jurídico español) y el nuevo tratamiento procesal del Derecho extranjero que la LEC 1/2000 dispone hacen de la aplicación del Derecho extranjero por los tribunales españoles un debate de la máxima actualidad e importancia. El presente estudio abordará los «problemas generales» de la aplicación de un Derecho extranjero (y su tratamiento procesal) por los tribunales españoles desde la perspectiva de la prueba del Derecho foráneo ante dichos órganos judiciales.
\end{abstract}

Palabras clave: Derecho Internacional Privado, Derecho extranjero, prueba, LEC $1 / 2000$.

Abstract: The change of the International Law social scene, the correlative and spectacular development of the Private International Law (which has became one of the most dynamic areas of the Spanish Legal Order, because of the EU Law boost) and the new procedural treatment of the Foreign Law given by the LEC 1/2000 have made the implementation of the Foreign Law by Spanish Courts a major actuality debate. The present article deals with the general problems of the implementation of a Foreign Law (and its procedural treatment) by Spanish Courts from the point of view of the proof of the Foreign Law before those Courts.

Key words: Private International Law, Foreign Law, proof, evidence, LEC $1 / 2000$

Sumario: I. Introducción. - II. Modelos teóricos de prueba del Derecho extranjero. 1. Los dos grandes modelos básicos. 2. La irresistible tendencia hacia un modelo de «prueba de oficio» del Derecho extranjero. - III. Antecedentes históricos. La Sala Civil del Tribunal Supremo y la prueba del Derecho extranjero. - IV. La LEC 1/2000 y la prueba del Derecho extranjero ante los tribunales españoles. 1. La prueba del Derecho extranjero: un sistema de «textura abierta». 2. Alegación del Derecho extranjero 3. Necesaria prueba del Derecho extranjero. 4. Momento procesal oportuno para probar el Derecho extranjero. 
5. Medios técnicos apropiados para probar el Derecho extranjero. A) Prueba del Derecho extranjero por las partes. B) Prueba del Derecho extranjero por el tribunal. 6. Objeto de la prueba del Derecho extranjero. 7. Carga de la prueba del Derecho extranjero. 8. Consecuencias jurídicas en el caso de falta de alegación y/o prueba del Derecho extranjero: las diferentes tesis. A) Tesis de la inadmisión de la demanda. B) Tesis de la «retroacción de actuaciones» procesales. C) Tesis de la aplicación de oficio del Derecho extranjero. D) Tesis de la aplicación sustitutiva del Derecho material español. E) Tesis de la desestimación de la demanda. a) Exposición y fundamentos de la tesis. b) La tesis de desestimación de la demanda y la tutela judicial efectiva. c) La tesis de la desestimación de la demanda y el art. 218.1.II LEC. F) La Constitución y la falta de alegación y prueba del Derecho extranjero. 9. Prueba imposible del Derecho extranjero.

\section{Introducción}

1. En presencia de una situación privada internacional, las «normas de conflicto» españolas indican al tribunal español qué concreto Derecho estatal es aplicable para resolver el fondo del litigio. Como es lógico, son numerosas las ocasiones en las que tales normas de conflicto conducen a la aplicación de un Derecho extranjero. El tribunal español debe aplicar Derecho extranjero para resolver el litigio surgido entre las partes. Pues bien, en tales supuestos, surge la cuestión del «tratamiento procesal de tal Derecho extranjero» en el contexto del proceso que se sigue en España: ¿debe alegarse el Derecho extranjero?; ¿debe probarse?; ¿quién debe o puede probar el Derecho extranjero?; ¿qué ocurre si el Derecho extranjero no se prueba en el proceso que se sigue en España? ¿Qué medios de prueba pueden emplearse para probar el Derecho extranjero? ¿Debe probarse siempre el Derecho extranjero? Todas estas cuestiones han preocupado a la doctrina española y extranjera especializada en el Derecho internacional privado (= DIPr.) desde hace muchos años. Pero lo cierto es que dichas cuestiones están hoy en día de rabiosa y plena actualidad debido a varios factores. Primero: el cambio de escenario social del Derecho internacional privado (las «situaciones privadas internacionales» son más numerosas y variadas que nunca antes). Segundo: el correlativo y espectacular desarrollo del Derecho internacional privado (que ha pasado a ser, gracias fundamentalmente al impulso del Derecho Comunitario, uno de los sectores con mayor dinamismo del Ordenamiento Jurídico español). Tercero: España cuenta con una nueva Ley de enjuiciamiento civil (= LEC 1/2000) que se ha ocupado de los problemas de «tratamiento procesal del Derecho extranjero», antes contemplados en el Código Civil (art. 12.6) tras la reforma de su Título Preliminar en 1974. No es de extrañar, pues, que la doctrina española más reciente haya dedicado esfuerzos de envergadura a aclarar cuál es el régimen jurídico de la prueba del 
Derecho extranjero ante los tribunales españoles que rige desde el 7 enero $2001^{1}$.

2. El presente estudio abordará los «problemas generales» de la aplicación, por tribunales españoles, de un Derecho extranjero. Por consiguiente, quedan al margen de este ensayo las cuestiones relativas a la aplicación extrajudicial del Derecho extranjero, esto es, la aplicación del Derecho extranjero por parte de Encargados del Registro civil, Notarios, Agentes Diplomáticos y Consulares de España en el extranjero y Registradores de la Propiedad. Igualmente, ciertos problemas concretos relacionados con la aplicación del Derecho extranjero por tribunales españoles quedarán también excluidos del presente análisis, problemas tales como la llamada «aplicación integral» del Derecho extranjero, el reenvío (aplicación de las normas de DIPr. extranjero que conducen a la aplicación de normas materiales de otro Derecho estatal), la aplicación de las normas de Derecho Público pertene-

${ }^{1}$ A. L. Calvo Caravaca / J. Carrascosa González, Derecho internacional privado, vol.

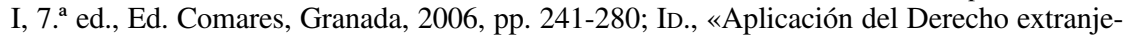
ro en España y la nueva LEC», Tribunales de Justicia, nov. 2000, n. 11, pp. 1155-1170; ID., «Normas de conflicto, aplicación del Derecho extranjero en España y nueva LEC», AEDIP, núm. 1, 2001, pp. 215-237; ID., «El Derecho extranjero y el TS: la Sala de lo Social contraataca», AEDIP, 2002, pp. 103-114; ID., «La prueba del derecho extranjero en la nueva Ley española de Enjuiciamiento Civil 1/2000», Diario La Ley, 2005, núm. 6178 de 28 enero 2005, pp. 1-7; ID., «The Proof of Foreign Law in the New Spanish Civil Procedure Code 1/2000», IPRax, 2005-2, pp. 170-174; ID., «El Tribunal Constitucional y el Tribunal Supremo ante la falta de alegación y prueba del Derecho extranjero (en torno a la STS, Social, de 4 noviembre de 2004)», Diario La Ley, núm. 6238 de 25 abril 2005, pp. 1-11; P. ABARCA JunCo / M. GómEZ JENE, «Alegación y prueba del Dcho. Extranjero en el procedimiento laboral», Rev. Esp. Der. Trabajo, sept.-oct. 2003 núm. 119, pp. 713-737; ID., «De nuevo sobre la alegación y prueba del Derecho extranjero en el procedimento laboral: A propósito de la STS (Social) de 4 noviembre 2004)», Rev. Esp. Der. Trabajo, abril-junio 2005, n. 126, pp. 119130; S. ÁlVAREZ GONZÁLEZ, «La aplicación judicial del Derecho extranjero bajo la lupa constitucional», REDI, 2002-I, pp. 205-223; F. CALVO BABío, «Problemas para probar Derecho extranjero en procedimientos judiciales españoles», Iuris, n. 93, 2005, pp. 85-61; L. CARBALLO PIÑEIRO, «El carácter imperativo de la norma de conflicto y la prueba del Derecho extranjero: Una relectura en clave procesal y constitucional», AEDIP, núm. 1, 2001, pp. 483-503; L. CARRILlo Pozo, «Alegación y prueba del Derecho extranjero en el ámbito laboral y tutela judicial efectiva», Rev. Esp. Dcho. Trabajo, núm. 111, mayo-junio 2002, pp. 451-473; ID., «Una doctrina constitucional sobre alegación y prueba de la Ley extranjera», Ar. Social, 2003, núms.7-8, pp. 53-84; F. J. Garcimartín AlfÉrez, Sobre la norma de conflicto y su aplicación procesal (cinco cuestiones clásicas), Madrid, Tecnos, 1994; ID., «Nota a STS 17 diciembre 1991», REDI, 1992, vol. XLIV, pp. 239-243; F. GARAU Sobrino, «La prueba del Derecho extranjero en la nueva LEC», $R G D$, n. 678-679, marzo-abril 2001, pp. 2343-2366; A. MARÍn LóPEZ, «La prueba de la Ley extranjera en la nueva LEC», AEDIP, núm.1, 2001, pp. 305-423; V. CuARTERo RuBio, «Prueba del Derecho extranjero y tutela judicial efectiva», Derecho Privado y Constitución, n. 14, 2000, pp. 21-71; J. MASEDA RODRíGUEZ, «La aplicación judicial del Derecho extranjero: el nuevo régimen de la LEC y la reciente jurisprudencia del Tribunal Constitucional», Actualidad Civil, n. 12, 2002, pp. 413-446. 
cientes al Derecho extranjero, la «segunda calificación», el «conflicto internacional transitorio» (ausländisches intertemporales Sachrecht), la cuestión de la aplicación en España de normas de Derecho extranjero contrarias a la Constitución extranjera del país cuyo Derecho se trata de aplicar, la interpretación del Derecho extranjero, los conocidos como «problemas de adaptación» (Angleichung), la aplicación de Leyes de Estados no reconocidos por España, el recurso de casación por infracción del Derecho extranjero, y la excepción del «orden público internacional» (ordre public / Public Policy / Voberhaltsklausel).

\section{Modelos teóricos de prueba del Derecho extranjero}

\section{Los dos grandes modelos básicos}

3. Dos «modelos teóricos» básicos se han propuesto como respuestas globales para regular satisfactoriamente la cuestión de la aplicación y prueba del Derecho extranjero. Con variantes y matices importantes, los distintos Estados siguen las líneas básicas de uno u otro «modelo» ${ }^{2}$. Se trata de los siguientes.

4. a) Modelo de aplicación del Derecho extranjero a instancia de parte. El Derecho extranjero lo deben probar las partes. Este modelo descansa en varios argumentos: 1) El Derecho extranjero es un mero «hecho procesal» $y$ no es «Derecho». Como explica H. MuIR-WATT, el Derecho extranjero no se puede considerar como «Derecho», ya que si así fuera, se estarían aplicando, en un país, los «mandatos soberanos» dictados por otro país, lo que comportaría una lesión intolerable de la Soberanía estatal del país cuyos tribunales conocen del asunto ${ }^{3}$. Como el Derecho extranjero es un «hecho proce-

${ }^{2}$ A. L. Calvo Caravaca / J. Carrascosa González, Derecho internacional privado, vol.

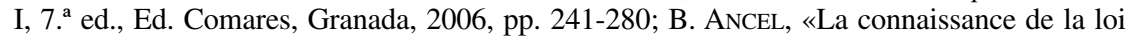
étrangere applicable», Droit international et droit communautaire, París, Centre culturel portugais, 1991, pp. 87-95; D. BuREAU, «L'accord procédural à l'epreuve», RCDIP, 1996, pp. 587-620; S. M. CARBONE, «Il diritto straniero ed il giudice italiano: presente e prospettive di sviluppo», RDI, 1991, vol. LXXIV, pp. 838-849; M. JÄNTERÄ-JAREBORG, «Foreign law in national courts: a comparative perspective», $R C A D I$, vol. 304, 2003, pp. 181-385; W. KRAUSE, Auslandisches Rechts und deutscher Zivilprozess, Constanza, 1990; U. KüsTER, Die Ermittlung ausländischen Rechts im deutschen Zivilprozess und ihre Kostenfragen. Eine rechtsvergleichende Untersuchung, Hannover, Diss. 1995; Y. LEQUETTE, «L'abandon de la jurisprudence Bisbal (a propos des arrets de la Premiere Chambre Civile des 11 et 18 octobre 1988)», RCDIP, 1989, pp. 277-339; H. LEWALD, «Le contrôle des cours suprêmes sur l'application des lois étrangeres», RCADI, 1936, vol. 57, pp. 201-324; P. MAYER, «Le juge et la loi étrangère», RSDIDE, 1991, pp. 481-501; M. RUBINO-SAMMARTANO, «Il giudice nazionale di fronte alla legge straniera», RDIPP, 1991, pp. 315-344; I. ZAJTAY, «The Application of Foreign Law», IECL, vol. 2, Chapter 14, Tübingen, Den Haag, Paris, New York, 1972.

${ }^{3}$ H. Muir-WaTt, «Loi étrangère», Dalloz Droit international, 2. a ed. , 1998, p. 2. 
sal», lo deben probar las partes interesadas: los tribunales permanecen al margen de la prueba de los «hechos». Este primer argumento es, hoy en día, totalmente insostenible. En efecto, aplicar un Derecho extranjero en otro país en calidad de «Derecho», no lesiona en absoluto la Soberanía de ese otro país, pues el Derecho extranjero no es Derecho «vigente» en otro país, sino que sólo «se aplica» en otro país. Y de ello deriva que las legislaciones más modernas abandonen de modo radical la ecuación «Derecho extranjero $=$ hecho procesal». Dicha ecuación es falsa, por dos motivos. Primero, porque al comprobarse que la aplicación de un Derecho extranjero no daña la Soberanía del Estado cuyos tribunales conocen del asunto, no existe ninguna necesidad de concebir el Derecho extranjero como un mero y simple «hecho procesal». Segundo, porque el Derecho extranjero no desarrolla las funciones que despliegan los hechos procesales. El Derecho extranjero resuelve el litigio (al igual que hace el Derecho nacional cuando es aplicable al fondo del asunto). Desarrolla, por tanto, una función estrictamente jurídica. Los hechos procesales no resuelven el fondo del litigio, no resuelven la controversia. 2) El Derecho «extranjero» es «extranjero». Por ello no se puede tratar «igual» que el Derecho del país cuyos tribunales conocen del asunto. Consecuencia: el principio jura novit curia sólo debe alcanzar al Derecho nacional y nunca al Derecho extranjero. 3) La aplicación del Derecho extranjero, en la mayor parte de los supuestos, beneficia exclusivamente «intereses particulares» y no «intereses generales», razón por la que deben ser las partes interesadas las que prueben el Derecho extranjero. Son países que siguen este primer modelo, si bien con matices importantes, entre otros, Francia, España, Reino Unido, EE.UU., Argentina, Brasil, Quebec, etc.

5. b) Modelo de aplicación del Derecho extranjero de oficio por el tribunal. El Derecho extranjero lo debe probar el tribunal que conoce del asunto. Este modelo se construye sobre un argumento clave: el Derecho extranjero es «Derecho» (no por aplicarse en otro país, el Derecho extranjero deja de ser «Derecho»), y desarrolla una «función estrictamente jurídica» (el Derecho extranjero «resuelve el caso», zanja la controversia). Por ello, el Derecho extranjero debe ser tratado igual que el Derecho del país cuyos tribunales conocen del asunto. Es decir: el tribunal debe probar o acreditar el contenido del Derecho extranjero (jura novit curia). Son países que siguen este segundo modelo la inmensa mayoría de los que disponen de Leyes especiales de DIPr. promulgadas recientemente (Austria, Turquía, Suiza, Italia, Venezuela, Bélgica, etc.), así como Alemania, Japón, y muchos Estados de América del Sur.

6. El enfrentamiento entre ambos modelos es difícil de resolver. La razón es que el Derecho extranjero es «Derecho», pero también es «extranjero». Si se considera que el carácter «extranjero» del Derecho extranjero es determinante, entonces el primer modelo es preferible; si por el contrario se entiende que lo determinante es que el Derecho extranjero es «Derecho», el segundo modelo debe imponerse. Pero tras esta «batalla jurídica», late otra batalla 
social y económica, a menudo injustamente olvidada y postergada. Probar el Derecho extranjero es caro, lleva tiempo y es complicado. Pues bien, los Estados que prefieren un modelo de prueba del Derecho extranjero «a instancia de parte» estiman que, como los casos regidos por el Derecho extranjero son escasos en la práctica judicial, el coste de su prueba lo deben soportar, por regla general, las partes afectadas, ya que la sociedad no tiene por qué pagar con tiempo y dinero lo que afecta a un «sector reducido de sujetos». Por el contrario, los Estados que optan por la aplicación de oficio del Derecho extranjero estiman que los casos internacionales son numerosos y por tanto es justo distribuir el coste de la prueba del Derecho extranjero entre toda la sociedad, ya que toda la sociedad está implicada, de modo que es oportuno crear «estructuras públicas de prueba del Derecho extranjero» y ordenar a los tribunales que prueben, de oficio, el Derecho extranjero.

\section{La irresistible tendencia hacia un modelo de «prueba de oficio» del Dere- cho extranjero}

7. En la actualidad existen datos poderosos que inducen a pensar que la tendencia hacia una sistema de «prueba de oficio» de la Ley extranjera es inevitable e irreversible. Todo arranca de un postulado elemental: la creciente internacionalización de la sociedad en los países occidentales provoca un aumento espectacular de las situaciones jurídicas reguladas por un Derecho extranjero. Este «nuevo escenario» comporta varias consecuencias.

Primera. En los primeros años de este siglo XXI, la aplicación del Derecho extranjero es una cuestión que afecta ya a toda la sociedad y no una cuestión que implica a unos pocos sujetos. El porcentaje de litigios en los que se aplica un Derecho extranjero en Europa y también en España crece a ritmo exponencial. Llegará un momento en el que la mayor parte de los sujetos que habitan en España tendrán que litigar, alguna vez, con arreglo a un Derecho extranjero. Por ello, resulta conveniente establecer una «estructura pública de prueba del Derecho extranjero», en la que los tribunales prueban de oficio el Derecho extranjero a un coste mucho menor que el que implica probar el Derecho extranjero mediante «estructuras privadas» por los particulares implicados en situaciones privadas internacionales. Ello explica por qué las nuevas Leyes especiales de DIPr. en los diferentes Estados (Italia, Suiza, Rumanía, etc.), han apostado decididamente por un modelo de «prueba de oficio» del Derecho extranjero.

Segundo. El DIPr. español se está llenando de normas de conflicto «comunitarizadas», elaboradas por las instituciones comunitarias sobre la base de los arts. 61 y $65 \mathrm{TCE}^{4}$. Pues bien, estas nuevas normas de DIPr.

${ }^{4}$ S. BARIATTI, «Prime considerazioni sugli effetti dei principi generali e delle norme materiali del trattato CE sul diritto internazionale privato comunitario», RDIPP, 2003, pp. 671-706; J. BASEDOW, «The communitarisation of the conflict of laws under the treaty of 
«comunitarizadas» sólo son efectivas si se garantiza al máximo nivel la prueba del Derecho extranjero, pues en caso contrario, la «armonía internacional de soluciones» buscada con dichas normas, se desvanece (sin una garantía elevada de que el Derecho extranjero designado por estas normas de conflicto comunitarizadas se va a aplicar, renace el Forum Shopping y las soluciones distintas de Estado miembro a Estado miembro). Por ello, como recuerda M. JÄNTERÄ-JAREBORG, el art. 65.c) TCE permite que la UE elabore normas uniformes que impongan la prueba de oficio del Derecho extranjero en todos los Estados miembros, algo que sucederá con toda probabilidad en un futuro no lejano 5 .

Las consecuencias del nuevo escenario de los litigios internacionales entre particulares conduce inevitablemente a una conclusión: la tendencia hacia un sistema de prueba de oficio del Derecho extranjero parece irreversible.

Amsterdam», CMLR, 2000, p. 687-ss. ; ID. , «European Conflict of Laws Under the Treaty of Amsterdam», en P. J. Borchers / J. Zekoll (EDS. ), Essays F. K. Juenger, Nueva York, 2001, pp. 175-192; K. BoELE-WoELKI, «Unification and Harmonisation of Private International Law in Europe», Liber Amicorum K. Siehr, TMC Asser Press, The Hague, 2000, pp. 61-77; TH. M. DE BoER, «Prospects for European Conflicts Law in the Twenty-First Century», Essays F. K. Juenger, Nueva York, 2001, pp. 193-214; S. BRUINIER, Der Einflusss der Grundfreiheiten auf das internationale Privatrecht, Frankfurt am Main, Lang, 2003; A. L. CAlvo CARAVACA, «El DIPr. de la Comunidad Europea», International Law. Revista colombiana de Derecho internacional, núm. 2, diciembre 2003, pp. 277-300; H. GAUDEMETTALLON, «De l'utilité d'une unification du droit international privé de la famille dans l'Union Européenne», Estudos Magalhães Collaço, vol. I, Almedina, Portugal, 2002, pp. 159-185; H. U. Jessurun D'OliveirA, «The EU and a metamorphosis of Private International Law», Essays P. North, Oxford UP, 2002, pp. 111-136; СH. KOHLER, «Interrogations sur les sources du droit international privé européen après le traité d'Amsterdam», RCDIP, 1999, pp. 130; P. LAGARDE, «Développements futurs du droit international privé dans une Europe en voie d'unification: quelques conjetures», RabelsZ, 2004, pp. 225-243; S. LeIBLE / A. STAUDINGER, «El art. 65 TCE: ¿carta blanca de la Comunidad Europea para la unificación del DIPr. y procesal?», AEDIP, vol. I, 2001, pp. 89-115; РH. -E. PARTSCH, Le droit international privé européen de Rome a Nice, Bruxelles, Lacier, 2003; P. PiCone (a cura di), Diritto internazionale privato e Diritto comunitario, Cedam, Padova, 2004; F. POCAR, «La comunitarizzazione del DIPrivato: una european conflict of laws revolution», RDIPP, 2000, pp. 873884; F. Viangalli, La théorie des conflits de lois et le droit communautaire, Aix-en Provence, 2004; R. WAGNER, «EG-Kompetenz für das Internationale Privatrecht in Ehesachen?», RabelsZ, 2004, pp. 119-153; K. WANNEMACHER, Die Aussenkompetenzen der EG im Bereich des Internationalen Zivilverfahrensrechts: des räumliche Andwendungsbereich des Art. 65 EGV am Beispel der EuGVO und der EheVO, Frankfurt am Main, Lang, 2003; M. WILDERSPIN / A. -M. Rouchaud-JoËT, «La compétence externe de la Communauté européenne en droit international privé», RCDIP, 2004, pp. 1-48.

${ }^{5}$ M. JÄNTERÄ-JAREBORG, «Foreign law in national courts: a comparative perspective», $R C A D I$, vol. 304, 2003, pp. 181-385. 


\section{Antecedentes históricos. La Sala Civil del Tribunal Supremo y la prueba del Derecho extranjero}

8. El tratamiento procesal del Derecho extranjero en España quedó sujeto a una serie de reglas elaboradas por la Sala Primera del TS en el siglo XIX antes de la promulgación del Código Civil en 1889. Ello fue así porque el citado Código Civil de 1889, en su redacción originaria, guardó un total silencio sobre el «tratamiento procesal del Derecho extranjero». Las reglas creadas por el TS pueden resumirse en tres grandes proposiciones.

1) Proposición uno: el Derecho extranjero no se trata procesalmente como Derecho, pues ello supondría un atentado contra la Soberanía española, ya que supondría aceptar en España «mandatos de Soberanos extranjeros». Por ello, para el TS, el Derecho extranjero se comporta como un «hecho procesal». Como tal, el Derecho extranjero debe alegarse y probarse «a instancia de parte» (STS 21 junio 1864, STS 20 marzo 1877, STS 13 enero 1885, STS 26 mayo 1887, STS 28 enero 1896, STS 7 noviembre 1896, STS 19 noviembre 1904, STS 1 febrero 1934, STS 9 enero 1936, STS 17 julio 1937, STS 29 septiembre 1956, STS 16 diciembre 1960, STS 30 junio 1962, STS 6 junio 1969, STS 5 noviembre 1971).

2) Proposición dos: el juzgador tiene la facultad, pero no la obligación, de «intervenir» en la prueba del Derecho extranjero. Pero mucho cuidado: nunca jamás el TS indicó cuándo el juez «podía intervenir» en la prueba del Derecho extranjero, por lo que ello resultaba discrecional (se hablaba de «discrecionalidad técnica»), pero lo cierto es que, más que discrecional, la intervención del tribunal al efecto resultaba verdaderamente arbitraria (STS 26 mayo 1887, STS 13 enero 1885, STS 30 enero 1930, STS 21 febrero 1935, STS 16 junio 1935, STS 16 octubre 1940, STS 14 diciembre 1940, etc.).

3) Proposición tres: si el Derecho extranjero no se prueba por la parte interesada, el tribunal español debía fallar con arreglo al Derecho material español (Back To Lex Fori Rule).

9. Las reglas elaboradas por la Sala Primera del TS en el siglo XIX siguieron observándose por los tribunales españoles de un modo prácticamente unánime durante todo el siglo Xx. Los cambios legislativos no tuvieron la más mínima incidencia en ello. Primero, porque el Código Civil de 1889 carecía de regulación sobre la cuestión. Segundo, porque aunque a partir de 1974, el art. 12.6.II Cc. se ocupó de la cuestión, su texto era confuso, ambiguo, impreciso y nebuloso. Algunas sentencias trataron de realizar una «lectura peculiar» del art. 12.6.II Cc. orientada a admitir una «obligación del juez» de probar el Derecho extranjero en defecto de prueba por las partes (SAT Valencia 3 abril 1982, SAP Oviedo, Sec. 4. ${ }^{\text {a }} 13$ marzo 1990; SAP Granada, Sec. 3. ${ }^{\text {a }}, 12$ febrero 1992). Pero es cierto que, en la práctica, la inmensa mayoría de los tribunales españoles con la Sala Civil del TS a la cabeza, siguió aferrada con cadenas irrompibles a las «tres proposiciones» que la 
Sala Primera del TS había elaborado en el siglo XIX (STS 12 enero 1989, STS 11 mayo 1989, STS 7 septiembre 1990, STS 10 diciembre 1990, STS 16 julio 1991, STS, 17 diciembre 1991, STS 23 octubre 1992, STS 31 diciembre 1994, STS 15 noviembre 1996, STS 25 enero 1999, STS 9 febrero 1999, STS 5 junio 2000, STS 13 diciembre 2000, STS 17 julio 2001; también SAP Castellón 25 abril 2000, SAP Madrid 23 noviembre 2000). En resumen: para el TS, el art. 12.6.II Cc. y la Constitución española de 1978 no tuvieron la más mínima incidencia en la cuestión del tratamiento procesal del Derecho extranjero. Todo cambia para que todo siga igual, parecía pensar y decir la Sala Primera del Tribunal Supremo.

\section{La LEC 1/2000 y la prueba del Derecho extranjero ante los tribuna- les españoles}

\section{La prueba del Derecho extranjero: un sistema de «textura abierta»}

10. La regulación actual de la aplicación y prueba del Derecho extranjero se encuentra en el art. 281.2 LEC. El precepto indica: «También serán objeto de prueba la costumbre y el derecho extranjero. (...) El derecho extranjero deberá ser probado en lo que respecta a su contenido y vigencia, pudiendo valerse el tribunal de cuantos medios de averiguación estime necesarios para su aplicación».

11. La regulación de la prueba del Derecho extranjero en la LEC es sólo «parcial» (no exhaustiva). Esta afirmación debe ser entendida en dos sentidos.

12. En primer lugar, lo que la LEC regula en relación con la alegación y prueba del Derecho extranjero es una regulación «de líneas generales». En palabras más elegantes, puede afirmarse que el art. 281.2 LEC contiene un sistema de «textura abierta» en relación con la prueba del Derecho extranjero (F. J. GARCIMARTín ALFÉREZ ${ }^{6}$ ). Ello significa que el legislador español ha renunciado a elaborar en la LEC una regulación exhaustiva y minuciosa de la prueba del Derecho extranjero. Pudo hacerlo y no lo hizo. Pudo haber concretado cuáles son los medios de prueba del Derecho extranjero, el momento procesal oportuno al efecto, pudo fijar rígidamente la obligación del tribunal y/o de las partes de probar el Derecho extranjero en todos o en algunos procesos... Y no lo hizo. El legislador eligió otro camino: proporcionar las «líneas maestras» del régimen jurídico de la prueba del Derecho extranjero, y dejó intencionadamente a los tribunales la tarea de elaborar respuestas con-

${ }^{6}$ F. J. Garcimartín AlFÉREZ, «Nota a STS 17 diciembre 1991», REDI, 1992, vol. XLIV, pp. 239-243. 
cretas a las cuestiones no reguladas en la LEC. Por ello, la regulación española sobre la prueba del Derecho extranjero es una combinación de «regulación legal básica» y de «regulación jurisprudencial de desarrollo». Esta opción en favor de un «sistema flexible» debe ser valorada de modo muy positivo. En efecto, ello permite que la tradicional rigidez de las normas de Derecho internacional privado deje paso a un régimen jurídico «inteligente», capaz de adaptarse a las situaciones privadas internacionales en el contexto cambiante de la globalización propio del siglo $\mathrm{XXI}^{7}$. Sistemas rígidos y regulaciones reglamentistas de la prueba del Derecho extranjero son inconvenientes, aunque ciertos autores, como por ejemplo S. ÁlVAREZ GonZÁLEZ, defiendan tales regulaciones en nombre de una presunta «seguridad jurídica», prinicipio que nada tiene que ver con la cuestión ${ }^{8}$. Valga al efecto recordar las palabras de V. ITURRALDE SESMA, vertidas, a su vez, sobre el clásico trabajo de E. ZITELMANN: «nunca se conseguirá comprender en los limitados artículos de un código la abundancia inagotable de la vida real con todas las cuestiones jurídicas que ofrece; siempre surgen en la vida casos nuevos que ningún legislador hubiera podido prever» ${ }^{9}$. O como escribe $\mathrm{A}$. $\mathrm{NIETO}^{10}$, «el ordenamiento jurídico positivo no regula - y salvo excepciones, no puede regular-, casos individuales. La casuística es tan amplia que no se puede detallar». Las reglas para llevar a cabo la prueba del Derecho extranjero deben ser, necesariamente, «reglas generales y flexibles» y no reglas puntillosas y excesivamente particulares, singulares y por tanto, rígidas. Serían unas reglas inútiles. Ello es así porque sólo las normas jurídicas que contienen «enunciados generales» son «justas» (proporcionan una «igualdad de tratamiento legal») y «útiles» (una norma formulada para casos singulares es «poco efectiva»: sólo se aplicaría en contadas ocasiones) ${ }^{11}$. Y como nihil nuovo sub sole, ya decía el mismísimo ARISTÓTELES que por el hecho de que «la ley necesariamente es siempre general», eso no quiere decir que la ley sea «menos buena». La generalidad no es un «defecto» de las normas jurídicas, como impropiamente opinan algunos: es una característica consustancial a ellas. Pues bien, al presentarse como «reglas generales», las normas que rigen la prueba del Derecho extranjero escogen como «centro de su regulación» un «caso-tipo», el «caso general», el «caso más frecuente» (el «caso

7 J. Carrascosa González, Desarrollo judicial y Derecho internacional privado, Ed. Comares, Granada, 2004, pp. 205-211.

${ }^{8}$ S. Álvarez GonzÁLEZ, «Aplicación judicial del Derecho extranjero: la desconcertante práctica judicial, los estériles esfuerzos doctrinales y la necesaria reforma legislativa», Diario La Ley, núm. 6287 de 4 julio 2005.

${ }^{9}$ V. ITURRALDE SESMA, Lenguaje legal y sistema jurídico (cuestiones relativas a la aplicación de la Ley), Tecnos, Madrid, 1989, p. 181; E. ZitelmanN, «Las lagunas del Derecho», RGLJ, vol. 140, 1922, pp. 544-547.

${ }^{10}$ A. NieTo, El arbitrio judicial, Ariel Derecho, Barcelona, 2000, p. 228.

${ }^{11}$ S. C. Symeonides, «The American Choice-of-Law Revolution in the Courts: Today and Tomorrow», RCADI, 2002, vol, 298, pp. 9-448, esp. p. 406. 
normal» o «caso ordinario» en terminología aristotélica) ${ }^{12}$. Por ello, no es apropiado aplicar la norma general de DIPr. relativa a la prueba del Derecho extranjero a ciertos «casos particulares». La ley no disimula «los vacíos que deja»: el legislador y la ley son conscientes de la «finitud de la ley», de su carácter «necesariamente incompleto». Por tanto, la «norma general» de DIPr. relativa a la prueba del Derecho extranjero no se puede aplicar literalmente a los «casos con perfiles específicos». Ello causaría «injusticias» y «resultados absurdos», ya que la norma general no fue diseñada para tales «casos con perfiles específicos». Solución: las «normas generales» deben ser objeto de las oportunas «reducciones teleológicas» por parte del intérprete. El tribunal debe llevar a cabo un «desarrollo judicial del DIPr.». El legislador es consciente de que la «Ley general» necesita un «desarrollo particular» por parte de los jueces. El legislador pudo establecer en la LEC 1/2000 un régimen de prueba del Derecho extranjero mucho más particularizado, más rígido, con la intención de cubrir hipótesis más concretas y singulares. Pero como antes se dijo, el legislador, pudiendo perfectamente haberlo hecho, no lo hizo. Esta «dejación del legislador» es deliberada y no tiene nada que ver con su falta de respeto por la «seguridad jurídica», como equivocadamente se ha escrito por algún autor ${ }^{13}$. Por eso, puede afirmarse, sin riesgo, que el legislador otorga con frecuencia, en el contexto del DIPr., una «habilitación legal» al juez y al operador jurídico para que éstos encuentren la solución más apropiada en los casos de «lagunas ocultas» de DIPr., en palabras de K. KREUZER $^{14}$.

Descendiendo a detalles, la LEC se limita a afirmar que 1) el Derecho extranjero debe ser probado (pero no indica si debe probarse el Derecho extranjero «proceso por proceso», es decir, cada vez que un Derecho extranjero sea aplicable); 2) debe probarse el «contenido» y la «vigencia» del Derecho extranjero (nada dice de «otros extremos» relativos al Derecho extranjero cuya prueba había venido siendo exigida por la tradicional jurisprudencia del TS, como la «aplicabilidad al caso del Derecho extranjero», su «interpretación», etc.); 3) como regla general, la prueba del Derecho extran-

${ }^{12}$ Aristóteles, Moral a Nicómaco, Libro V, teoría de la Justicia, Capítulo X (De la equidad), colección Austral, Madrid, 2000, p. 234: «la ley necesariamente es siempre general (....) y así, en todas las cuestiones respecto de las que es absolutamente inevitable decidir de una manera puramente general, sin que sea posible hacerlo bien, la ley se limita a los casos más ordinarios, sin que disimule los vacíos que deja».

${ }^{13}$ S. Álvarez GonZÁlez, «Aplicación judicial del Derecho extranjero: la desconcertante práctica judicial, los estériles esfuerzos doctrinales y la necesaria reforma legislativa», Diario La Ley, núm. 6287 de 4 julio 2005.

${ }^{14}$ K. KREUZER, «Zur funktion von kollisionsrechtlichen Berichtigugsnormen», Z.f.Rvgl, 1992/3, p. 183: ID., «Berichtigungsklauseln im Internationalen Privatrecht», en Mélanges Imre Zajtay, Tübingen, 1982, pp. 295-331; J. D. GonZÁLEZ CAMPOS, «Diversification, spécialisation, flexibilisation et materialisation des règles de droit international privé», $R C A D I$, 2000, vol. 287, pp. 9-426, esp. p. 187. 
jero se practica «a instancia de parte» (art. 282 LEC, todas las pruebas se practicarán a instancia de parte, no sólo la prueba de los «hechos»), pero es cierto que caben «excepciones» a dicha regla (art. 281.2 LEC, aunque también es verdad que la LEC no indica «en qué casos» puede y/o debe intervenir el tribunal en la prueba del Derecho extranjero); 4) el «Derecho extranjero» es algo totalmente diferente de los «hechos procesales»: los hechos procesales están sujetos a unas reglas determinadas de prueba que no son aplicables tout court al Derecho extranjero.

13. En segundo lugar, existe toda una pléyade de aspectos relativos a la alegación y prueba del Derecho extranjero que la LEC no regula ni tangencialmente, ni nuclearmente, ni mediante «líneas generales». Como destaca con su agudeza habitual F. F. GARAU SOBRINO, son muy numerosos los «silencios» de la LEC sobre la prueba del Derecho extranjero ${ }^{15}$. En efecto, la LEC guarda silencio, al menos, sobre los siguientes aspectos: 1) ¿debe alegarse el Derecho extranjero?, ¿qué ocurre si ello no se hace?; 2) ¿debe probarse siempre, en cada proceso, el Derecho extranjero?; 3) ¿cuál es el momento procesal oportuno para probar el Derecho extranjero?; 4) ¿cuáles son los medios de prueba del Derecho extranjero?; 5) ¿quién debe o puede probar el Derecho extranjero?; 6) ¿qué ocurre si no se prueba el Derecho extranjero?; 7) ¿qué ocurre si resulta imposible probar el Derecho extranjero?

\section{Alegación del Derecho extranjero}

14. Los «hechos» deben alegarse al proceso en los términos del art. 399 LEC. Pero el Derecho extranjero no es un «hecho procesal»: el art. 281.2 LEC separa, con toda claridad, los «hechos» y el «Derecho extranjero». Esta distinción comporta varias consecuencias:

1) El Derecho extranjero no debe ser alegado por las partes como si fuera un «hecho procesal» más. La aplicación del Derecho extranjero a un caso concreto no depende de que las partes lo aleguen o no lo aleguen: deriva directamente de la norma de conflicto española.

2) Si una parte no alega un «hecho», éste no se toma en cuenta por el tribunal para fallar el caso, el hecho «desaparece del proceso», el hecho no existe (quod non est actis non est in mundo). Pero si una parte no alega el Derecho extranjero, éste no «desaparece» del proceso, porque sigue siendo el Derecho aplicable al caso, lo quieran o no lo quieran las partes, lo digan o no las partes, lo aleguen o no lo aleguen las partes.

3) La fundamentación jurídica de las pretensiones de las partes es siempre «objetiva». A cada pretensión corresponde una fundamentación jurídica

15 F. GARAu Sobrino, «La prueba del Derecho extranjero en la nueva LEC», $R G D$, n. 678-679, marzo-abril 2001, pp. 2343-2366. 
correcta. Es ésa y ninguna otra. Por ello, si un supuesto se rige por un Derecho extranjero, las partes deben fundar sus pretensiones en tal Derecho extranjero, y si no lo hacen y basan sus pretensiones, por el contrario, en el Derecho español, la pretensión debe ser desestimada. Y debe ser desestimada porque en tal caso, la fundamentación jurídica de la pretensión de las partes es incorrecta. El tribunal no tiene por qué hacer el trabajo de unos abogados que son profesionales de la defensa técnica de las partes. Si la fundamentación jurídica es incorrecta, la demanda, o la contestación a la demanda, se desestima, la pretensión jurídica se rechaza. No está correctamente fundada.

15. Y a todo esto, ¿qué afirma al respecto el Tribunal Supremo? Desde el siglo XIX hasta fechas muy recientes, el TS sostuvo lo siguiente en relación con la alegación del Derecho extranjero (STS 16 diciembre 1960, STS 10 diciembre 1966, STS 9 mayo 1988): a) el Derecho extranjero debe ser alegado siempre por las partes interesadas; b) la falta de alegación del Derecho extranjero por las partes conduce a la «no aplicación» del Derecho extranjero al supuesto; c) el momento procesal oportuno para la alegación del Derecho extranjero es la primera instancia y no la apelación ni la casación; d) el Derecho extranjero debe alegarse en las fases del proceso aptas para la aportación al proceso de «elementos de hecho»: hoy, en la demanda y contestación a la demanda.

Pues bien, la diferencia radical entre «hechos» $\mathrm{y}$ «Derecho extranjero», diferencia que se extrae del art. 281 LEC, aconseja rechazar la posición tradicional del TS sobre esta cuestión. Y efectivamente, parece claro que el Tribunal Supremo ha girado al compás de los nuevos tiempos procesales y ha abandonado su más que centenaria jurisprudencia. En efecto, la STS 10 junio 2005 abandona claramente la línea anterior del TS. Dice el TS en la referida sentencia: «En efecto, los hechos están regidos por la regla de aportación de parte (quod non est in actis non est in mundo), mientras que, en nuestro ordenamiento, el Tribunal está facultado para valerse de cuantos medios de averiguación estime necesarios para la aplicación del Derecho extranjero (artículo 12.6.2 CC, redacción anterior a la Ley 1/2000, de 7 de enero, LEC que era la vigente al interponerse la demanda, y artículo 281.2 de esta última Ley), lo que significa tanto como que debe aplicarlo si es que lo conoce $y$, al fin, que de hecho la aportación de parte sólo sea necesaria para suplir aquella información. Por otro lado, la norma jurídica extranjera viene designada por la de conflicto del foro, que pertenece al ordenamiento que el Tribunal debe aplicar de oficio (artículo 12.6 CC). Como consecuencia el derecho extranjero no tiene que ser alegado en el proceso por las partes para que el Juez deba tener en cuenta la designación que de él efectúa la norma de conflicto, por más que ello sea para darle el tratamiento procesal que corresponda. Lo que han de alegar las partes son hechos que, por la concurrencia de elementos extranjeros, se subsuman bajo la previsión de la norma de conflicto. Basta con tal alegación para 
que, como efecto de dicha norma, se considere que el litigio debe resolverse según el Derecho extranjero en ella designado». Es suficiente ahora subrayar las palabras clave de esta resolución, por lo que hace a la cuestión de la alegación del Derecho extranjero: «el derecho extranjero no tiene que ser alegado en el proceso por las partes para que el Juez deba tener en cuenta la designación que de él efectúa la norma de conflicto, por más que ello sea para darle el tratamiento procesal que corresponda». Esta sentencia de la Sala Primera del TS de 10 junio 2005 representa un giro de 180 grados respecto de la precedente y más que centenaria jurisprudencia del TS relativa a la «alegación del Derecho extranjero». Y aunque esta sentencia no es perfecta (perfection is not for this world), sí representa un avance espectacular en la doctrina de la Sala Primera del TS respecto a obsoletas posiciones anteriores.

\section{Necesaria prueba del Derecho extranjero}

16. El Derecho extranjero debe probarse. Así lo exige expresamente el art. 281.2 LEC. El TS ya había sostenido, desde antiguo, que el Derecho extranjero debía ser probado: STS 7 noviembre 1896, STS 9 enero 1936, STS 6 junio 1969, STS 12 noviembre 1976, STS 19 diciembre 1977, STS 23 octubre 1992, STS 18 febrero 1993, STS 10 marzo 1993, etc. El Derecho extranjero debe probarse porque el tribunal y las partes están obligados a conocer las normas jurídicas españolas escritas (art. 1.6 Cc.: jura novit curia), pero ni el tribunal ni las partes están obligados a conocer las normas jurídicas extranjeras (I. ZAJTAY ${ }^{16}$ ). Por tanto, el Derecho extranjero se sitúa en un plano de «inferioridad procesal» respecto del Derecho escrito español, que nunca hay que probar (F. MÉLIN $\left.{ }^{17}\right)$.

17. No obstante, el art. 281.2 LEC no indica si la prueba del Derecho extranjero debe realizarse en cada litigio regulado por un Derecho extranjero, «proceso por proceso» y si debe probarse siempre. Para afrontar el problema cabe formular una regla general y una excepción.

\footnotetext{
${ }^{16}$ I. ZAJTAY, «L'application du droit étranger, science et fiction», RIDC, 1971, pp. 49-59; ID., «L'applicazione del diritto straniero, scienza e fictio», RDIPP, 1972, pp. 755-767; ID., «The application of foreign Law», IECL, vol. III, chapter 14, 1972; ID., «La reception des droits étrangeres et le droit comparé», RIDC, 1957, pp. 686-713; ID., Contribution à l'étude de la condition de la loi étrangère en droit international privé français, París, 1958; ID., «Le traitement du droit étranger dans le procés civil. Étude de droit comparé», RDIPP, 1962, pp. 233-253; ID., «Grundfragen der Anwendung ausländischen Rechts im Zivilprozess», Zeitschrift für Rechtsvergleichung, 12, 1971, pp. 271-280.

${ }^{17}$ F. Mélin, Droit international privé, 2. a ed., Gualino éditeur, Paris, 2005, pp. 125-1138; ID., La connaissance de la loi étrangère par les juges du fond (Recherches sur l'inferiorité procédurale de la loi étrangère dans le procès civil), PUAM, 2002, pp. 55-69.
} 
a) Regla general: cada vez que debe aplicarse un Derecho extranjero, éste debe probarse en el concreto proceso. El Derecho extranjero se debe probar porque se parte del principio siguiente: las partes y el tribunal no conocen el Derecho extranjero ni tienen el deber de conocerlo.

b) Excepción: cuando el Derecho extranjero es conocido por el tribunal no parece necesario exigir que se pruebe «otra vez». La antes citada STS 10 junio 2005 lo dice obiter dictum: la prueba del Derecho extranjero y la aportación de las partes al respecto sólo es precisa si se desconoce el Derecho extranjero. En efecto: la prueba es necesaria cuando el contenido de la prueba (en este caso, el Derecho extranjero) se desconoce. Pero no en caso contrario. Cuando el juez y presumiblemente también las partes conocen a la perfección el Derecho extranjero no tiene sentido exigir la prueba de lo que se conoce. Así, en los casos en los que resulta muy frecuente la aplicación del Derecho extranjero y éste ha sido probado anteriormente de modo indubitado ante tribunales españoles, dicha prueba no será necesaria. Exigir la prueba de un Derecho extranjero cuando el juez y las partes lo conocen de modo exacto porque ya ha sido probado en otro proceso, es costoso y no es necesario. Esta «eximente de prueba» puede resultar muy útil en el caso de tribunales que ejercen sus funciones en poblaciones con un número elevado de extranjeros de una determinada nacionalidad y que aplican con mucha frecuencia un determinado Derecho extranjero. Un ejemplo será útil: la SAP Baleares 26 abril 2005 estima suficientemente probado el Derecho inglés relativo al régimen económico matrimonial porque su aplicación en Eivissa por los tribunales españoles es muy frecuente. Sería supérfluo y provocaría dilaciones inútiles volver a probar un Derecho extranjero cuyo contenido es conocido.

\section{Momento procesal oportuno para probar el Derecho extranjero}

18. Probar el «Derecho extranjero» no es probar «hechos procesales». El régimen de prueba del Derecho extranjero es sui generis. El Derecho extranjero debe poder probarse en primera instancia, en apelación y en casación.

19. Desde el siglo XIX, el TS sostiene que la prueba del Derecho extranjero debe realizarse, exclusivamente, en primera instancia. No cabe realizarla ni en apelación ni en casación. La explicación, para el TS, es lógica. El Derecho extranjero debe ser tratado, sin piedad, como un mero «hecho procesal»: por tanto, si el Derecho extranjero no se prueba en primera instancia, dicha posibilidad precluye, de modo que no cabe probarlo ni en apelación ni en casación. Sin embargo, la diferencia entre «hechos procesales» y «Derecho extranjero» es clarísima en la LEC (vid. el texto entero del art. 281 LEC). Por ello, la posición centenaria del TS debe revisarse drásticamente: debe aceptarse la prueba del Derecho extranjero en primera instancia, en apelación y en casación. 


\section{Medios técnicos apropiados para probar el Derecho extranjero.}

\section{A) PRUEBA DEl DERECho EXTRANJERo POR LAS PARTES}

20. La prueba del Derecho extranjero es una cuestión procesal. Por tanto, los medios de prueba a emplear deben ser los recogidos en la Ley que regula el proceso que se sigue ante los tribunales españoles (art. 3 LEC: Lex fori Regit Processum). Conclusión: sólo cabe utilizar los medios de prueba admitidos en la Ley española cuando se trata de probar el Derecho extranjero ante los tribunales españoles. La cuestión es muy relevante pues numerosos pleitos se deciden en un sentido u otro porque las partes prueban «correctamente» o «no correctamente» el contenido del Derecho extranjero aplicable al fondo del asunto. Varios apartados pueden distinguirse.

21. a) Medios de prueba apropiados para probar el Derecho extranjero. El art. 281.2 LEC no especifica qué concretos medios de prueba deben emplearse para probar el Derecho extranjero. Ante el silencio legal, distintas precisiones parecen oportunas.

Primera. El art. 281.2 LEC se refiere a la «prueba» del Derecho extranjero. Sin embargo, el Derecho extranjero, más que «probarlo», hay que «acreditarlo» (STS 3 marzo 1997). La prueba es una actividad diseñada para los «hechos procesales». El Derecho extranjero no es un mero «hecho procesal». Por ello, su acreditación no sigue estrictamente las reglas sobre la prueba rigurosa de los hechos procesales.

Segunda. El sistema de acreditación del Derecho extranjero es un sistema flexible, vertebrado en torno a la «libertad de medios probatorios»o «prueba libre» (SAP Huesca 14 diciembre 2005). De tal modo, se facilita la acreditación del Derecho extranjero y se potencia su correcta aplicación.

Tercera. No existe una «lista cerrada» de medios apropiados para acreditar el Derecho extranjero. El legislador no ha querido formular esa «lista cerrada», precisamente para facilitar la acreditación del Derecho extranjero. Por tanto, pueden emplearse todos los medios, instrumentos y herramientas técnicas que, por su propia naturaleza, sean adecuadas para acreditar el contenido del Derecho extranjero, ya sean o no «medios probatorios» de los admitidos en la LEC (art. 299.3 LEC por analogía). Ejemplos: el interrogatorio o dictamen de un «experto en Derecho extranjero» (Expert Witness), es apropiado para acreditar el Derecho extranjero, aunque el art. 299 LEC no lo incluye como «medio de prueba». La SAP Huesca 14 diciembre 2005 admitió un dictamen elaborado por la profesora de Derecho internacional privado Dra. Dña. PILAR Diago DiAgo en torno al Derecho matrimonial marroquí aplicable al régimen económico matrimonial.

Cuarta. En el caso de emplearse auténticos medios probatorios, como la prueba pericial o documental, éstos no tienen por qué ajustarse «de modo riguroso» a las exigencias que la LEC requiere a tales medios. 
Quinta. No todos los medios de prueba previstos en la Ley española para probar «hechos procesales» (art. 299.1 y 2 LEC) son apropiados para acreditar el Derecho extranjero. Para probar el Derecho extranjero sólo pueden utilizarse los medios de prueba que permitan constatar con certeza el contenido del Derecho extranjero. Así, por ejemplo, el «reconocimiento judicial» no es un «medio idóneo» para probar el Derecho extranjero. Sin embargo, la interrogación de un «experto en Derecho extranjero» (Expert Witness) sí que lo es, como también los «documentos públicos» o el «dictamen pericial».

Sexta. El objetivo de la acreditación del Derecho extranjero es convencer al tribunal del contenido de tal Derecho extranjero. Una vez conseguido dicho objetivo, el tribunal puede aplicar el Derecho extranjero y dar una solución al litigio. En general, todos los medios de acreditación del Derecho extranjero son de libre apreciación por el tribunal. Es decir, el tribunal valorará la fuerza probatoria de los diferentes medios de prueba con arreglo a las «reglas de la sana crítica» y no está vinculado por las pruebas y datos proporcionados por las partes. Sin embargo, los documentos públicos a través de los que se acredita el Derecho extranjero hacen «prueba plena» del «estado de cosas» que se contiene en tales documentos en torno al Derecho extranjero (arts. 317, 319 y 323 LEC).

23. b) Un solo medio de prueba es suficiente. Es perfectamente admisible que las partes, cuando prueban el Derecho extranjero, utilicen al efecto, exclusivamente, «un solo medio de prueba». Por ejemplo: prueba del Derecho extranjero, exclusivamente, mediante documentos públicos, o mediante dictamen pericial. En la prueba del Derecho extranjero las partes no están obligadas a utilizar varios medios de prueba cumulativamente, ni a emplear determinados medios de prueba. En la práctica, es frecuente la prueba de un Derecho extranjero, exclusivamente, mediante documentos públicos: STS 6 abril 1979, STS 12 enero 1989, STS 17 diciembre 1991, STS 16 julio 1991, STS 17 marzo 1992, STS 15 noviembre 1996, SAP Asturias 14 enero 2002, SAP Alicante 27 febrero 2004, SAP Guadalajara 14 enero 2004, SAP Baleares 31 marzo 2004.

24. c) Prueba mediante documentos públicos. El medio de prueba más utilizado por los particulares para probar el Derecho extranjero es la prueba mediante documentos públicos (art. 317 LEC). Son documentos públicos, por ejemplo, las certificaciones expedidas por la Subdirección General de Cooperación Jurídica Internacional del Ministerio de Justicia español sobre el contenido del Derecho extranjero. Estas certificaciones sólo pueden ser solicitadas por los tribunales, no por las partes. En 1998 se cursaron más de 600 peticiones de información sobre contenido de Leyes extranjeras. También son documentos públicos las certificaciones expedidas por funcionarios diplomáticos o consulares extranjeros acreditados en España, que deben presentarse legalizados y traducidos a idioma oficial español (arts. 323.3 y 144 LEC), así como las certificaciones expedidas por funcionarios diplomáticos 
o consulares españoles acreditados en el Estado cuyo ordenamiento jurídico se trata de probar.

25. d) Las «fotocopias». En los tribunales españoles, es frecuente que las partes aporten «simples fotocopias de diversas normas aisladas» (SAP Madrid 23 noviembre 2000, SAP Tenerife 13 abril 2004, SAP Alicante 12 mayo 2004, SAP Baleares 26 abril 2005). Tales documentos no son documentos públicos. Además, tales «fotocopias» no permiten probar con certeza el Derecho extranjero, por lo que no deben ser admitidas a tal efecto.

26. e) Documentos privados. Otros documentos no públicos, como son las «colecciones privadas» de Leyes o las obras doctrinales de autores extranjeros, poseen mayor peso probatorio que unas «simples fotocopias». Aunque la jurisprudencia del TS ha sido reacia durante años a admitir estos documentos para probar el Derecho extranjero, no hay por qué eliminarlos radicalmente como «medios de acreditación del Derecho extranjero». Habrá que decidir en cada caso concreto si un determinado documento privado, como por ejemplo un autorizado texto doctrinal extranjero, puede servir para acreditar el Derecho extranjero «con certeza».

27. f) Prueba pericial. También cabe utilizar para probar el Derecho extranjero, exclusivamente, la «prueba pericial» (art. 335 LEC). Tal peritaje puede consistir en un informe elaborado por «expertos en el Derecho extranjero» solicitado por las partes. No es necesario que tales «expertos» sean sujetos de la nacionalidad extranjera del país cuyo Derecho se trata de probar. Sin embargo, no es un medio de prueba admisible el llamado «informe de parte», un informe redactado por expertos legales a instancia de una parte, en el que el experto «toma partido» en favor de las pretensiones concretas de la parte (SAP Alicante 28 abril 2005).

28. g) Expert Witness. Como antes se ha avanzado sobre las palabras de la STS 3 marzo 1997, el Derecho extranjero, más que «probarlo», hay que «acreditarlo». Ello supone que pueden emplearse «medios de acreditación del Derecho extranjero que no sean, técnicamente hablando, "medios de prueba" admitidos como tales en las leyes procesales. Por ello, puede admitirse como «medio de acreditación del Derecho extranjero», el interrogatorio de «testigos expertos en Derecho extranjero» (Expert Witness), mecanismo muy difundido en otros países, pero poco utilizado hasta ahora en España.

29. h) Los «hechos admitidos» no son operativos. No cabe aceptar la prueba del Derecho extranjero mediante la «doctrina de los hechos admitidos». En general, como es sabido, en el proceso civil, los hechos admitidos por ambas partes no deben probarse. Pues bien, no es admisible que las partes «acuerden» que el Derecho extranjero no debe probarse, de forma que el contenido del Derecho extranjero sea fijado «por acuerdo entre las partes». El art. 281.3 LEC sólo es aplicable a los «hechos» no al «Derecho extranje- 
ro». Aunque en tiempos pasados alguna jurisprudencia admitió esta tesis en relación con el Derecho extranjero (STS 9 julio 1885, STS 9 enero 1936, STS 1 febrero 1934, STS 27 abril 1978 y STS 4 octubre 1982, SAT Baleares 17 julio 1984), tras la STS 5 noviembre 1971 debe estimarse que esta tesis no puede eximir de prueba al Derecho extranjero. El tenor del art. 281.2 LEC es muy claro al respecto.

30. Y de nuevo, a todo esto, ¿cuál es la posición de la Sala Primera del Tribunal Supremo al respecto? En un primer momento, el TS adoptó una postura muy liberal sobre los medios de prueba del Derecho extranjero (vid. STS 21 junio 1864, STS 22 octubre 1867, STS 18 marzo 1875, STS 20 marzo 1877 y STS 27 mayo 1913): parecía incluso admitir el conocimiento privado que el tribunal tenía del Derecho extranjero. Pero a partir de la STS 13 enero 1885, quién sabe por qué, la postura de la Sala Primera del TS sobre los medios de prueba del Derecho extranjero se concreta en esta rígida afirmación: el Derecho extranjero debe ser probado a través de «documentos públicos» $\mathrm{y}$, además, a través de «prueba pericial», un informe conjunto, legalizado y traducido, realizado por dos jurisconsultos del país extranjero cuya Ley debe probarse (STS 13 enero 1885, STS 19 noviembre 1904, STS 25 febrero 1926, STS 30 marzo 1928, STS 12 diciembre 1935, STS 6 diciembre 1961, STS 29 septiembre 1961, STS 30 junio 1962, STS 28 octubre 1968, STS 6 junio 1969, STS 5 noviembre 1971, STS 12 marzo 1973, STS 3 febrero 1975, STS 12 noviembre 1976, STS 27 abril 1978, STS 9 noviembre 1984, STS 23 octubre 1992, etc.). Pues bien, esta jurisprudencia debe hoy revisarse muy profundamente, pues en la actualidad, y tras la LEC $1 / 2000$ puede afirmarse que a) no es precisa una «prueba cumulativa» del Derecho extranjero mediante prueba documental y prueba pericial; b) cabe admitir la prueba del Derecho extranjero mediante documentos públicos y privados, o mediante otros medios de prueba, como el interrogatorio de un Expert Witness, siempre que tales medios permitan acreditar «con certeza» el Derecho extranjero.

\section{B) Prueba del Derecho extranjero por el tribunal}

31. El art. 281.2 LEC indica que el tribunal podrá valerse «de cuantos medios de averiguación estime necesarios» para la aplicación del Derecho extranjero. Es una «norma abierta». En particular, el tribunal puede utilizar para «averiguar» el Derecho extranjero los siguientes mecanismos:

1) Todos los medios de prueba previstos en la LEC siempre que sean adecuados para probar un Derecho extranjero. Ejemplo: documentos públicos como las certificaciones o informes consulares sobre el contenido del Derecho extranjero, o un dictamen pericial.

2) Otros «medios de averiguación» del Derecho extranjero, aunque no sean, estrictamente hablando, «medios de prueba». Entre estos otros «medios de averiguación» cabe citar los siguientes. 
Primero. El propio conocimiento que el tribunal tenga del Derecho extranjero (private Wissen). A tal efecto debe subrayarse lo siguiente: a) cuando el tribunal emplea su propio conocimiento del Derecho extranjero, el tribunal debe respetar el «principio de contradicción», para que las partes puedan debatir, en su caso, sobre el verdadero contenido del Derecho extranjero; b) el tribunal debe también hacer constar en la sentencia, con toda claridad, la norma extranjera y su contenido, a efectos de un posible recurso (STS 10 junio 2005, STSJ Com.Valenciana Sala Civil y Penal 22 septiembre 2005); c) Los medios o instrumentos a través de los cuales el tribunal adquiere conocimiento del Derecho extranjero son en sí mismos irrelevantes, siempre que permitan al tribunal un completo y profundo conocimiento del Derecho extranjero.

Segundo. Los mecanismos previstos en determinados convenios internacionales para la acreditación del Derecho extranjero. Ejemplos no faltan: Convenio europeo de Londres de 7 junio 1968 sobre información del Derecho extranjero, Convención interamericana sobre prueba e información del Derecho extranjero, hecha en Montevideo el 8 mayo 1979, y ciertos Convenios bilaterales firmados por España con países como Méjico (1 diciembre 1984), Brasil (13 abril 1989), República Checa y Eslovaquia (4 mayo 1987), China (2 mayo 1992), Bulgaria (23 mayo 1993), Marruecos (30 mayo 1997), ex-URSS (26 octubre 1990), Uruguay (4 noviembre 1987). El citado Convenio europeo de Londres de 7 junio 1968 sobre información del Derecho extranjero, completado por el Protocolo adicional hecho en Estrasburgo el 15 marzo 1978, establece un sistema de información de los ordenamientos jurídicos de los Estados partes. Cubre la información relativa al Derecho civil y mercantil, Derecho procesal civil y mercantil y Derecho sobre la organización judicial de los Estados partes. Cada Estado designa un órgano único, denominado «órgano de recepción», encargado de recibir las peticiones de datos de información jurídica y de dar curso a dichas peticiones. Cada Estado puede designar uno o varios «órganos de transmisión» encargados de recibir las peticiones de datos procedentes de sus Autoridades judiciales, y de transmitirlas al órgano de recepción extranjero competente. El convenio especifica el necesario contenido de la petición de datos (art. 4). El «órgano de recepción» formulará por sí mismo la respuesta a la solicitud de información. Debe proporcionarse una respuesta objetiva e imparcial sobre el Derecho del Estado requerido, incluyendo, en su caso, los textos legislativos y reglamentarios y de decisiones jurisprudenciales. Los datos contenidos en una respuesta no vinculan a la Autoridad judicial de la cual emanare la petición (art. 8). El órgano de recepción está obligado a dar curso a la petición de información (art. 10.1), salvo excepciones muy limitadas. La petición de datos jurídicos se redacta en la lengua oficial o en una de las lenguas oficiales del Estado requerido, o se acompañarán de una traducción en dicha lengua. La respuesta será redactada en la lengua del Estado requerido (art.14). El Convenio de Londres es generalmente ignorado por los tribunales de los 
Estados parte, España incluida, naturalmente. Aunque hay gloriosas excepciones que resplandecen en el firmamento jurisprudencial: la SAP Navarra 29 diciembre 2004 es un ejemplo evidente de un juzgador que maneja de modo escrupulosamente correcto el citado Convenio de Londres sobre información del Derecho extranjero.

Tercero. La Red Judicial Europea en materia civil y mercantil. Dicha Red Judicial fue creada por Decisión del Consejo 2001/470/CE, de 28 mayo 2001. Cada Estado miembro designa un «punto de contacto» al que los órganos judiciales de ese Estado miembro y de los demás Estados miembros puede dirigirse para solicitar información sobre el Derecho extranjero. Dichos «puntos de contacto» canalizan la solicitud para asegurar su buen fin: responden a la solicitud o la envían a las autoridades competentes o a las mejor situadas para dar satisfacción a la petición. También pueden ayudar directamente a los ciudadanos interesados.

Cuarto. Mucho más dudosos son algunos mecanismos propuestos recientemente, pero que actualmente no están previstos en las leyes: a) «Consulta a tribunal extranjero» (Preliminary Reference Procedure): un tribunal podría acreditar el contenido de un Derecho extranjero mediante «consulta directa» a un tribunal de dicho Estado. Ello podría ser especialmente útil en la UE para garantizar la correcta aplicación de las normas de DIPr. «comunitarizadas» (O. REMIEN $\left.{ }^{18}\right)$. El informe del tribunal extranjero podría ser vinculante (legally biding) o no (only with persuasive authority). El mecanismo es ingenioso, pero presenta inconvenientes: si el informe es vinculante, el tribunal que emite el informe condicionaría la labor del tribunal consultante, y si no es vinculante, el tribunal consultado tendrá poca motivación y además las partes no podrían tener acceso al tribunal consultado; b) «Transmisión del caso» (Forum Non Conveniens decided on the basis of the Applicable Law): el tribunal que debe aplicar Derecho extranjero podría «transmitir» la resolución del caso a un tribunal extranjero del país cuyo Derecho se trata de aplicar y tal tribunal resolvería el litigio. Es un Forum Non Conveniens oculto (M. JÄNTERÄ-JAREBORG, D. MC.CLEAN ${ }^{19}$ ). El mecanismo no tiene, hoy en día, cabida en el DIPr. europeo, que no lo ha previsto en ningún instrumento legal. Por ahora.

${ }^{18}$ O. Remien, «Jura Novit Curia und die Ermittlung fremden Rechts im europäischen Rechtsraum der Artt. 61 ff EGV - für ein neues Vorabentscheidungsverfahren bei mitgliedstaatlichen Gerichten», en J. BASEDOW Y OTROS, Aufbruch nach Europa- 74 Jahre MaxPlanck-Institut für Privatrecht, Mohr-Siebeck, Tübingen, 2001, pp. 617-631.

${ }^{19} \mathrm{M}$. JÄNTERÄ-JAREBORG, «Foreign law in national courts: a comparative perspective», $R C A D I$, vol. 304, 2003, pp. 181-385; D. MCCLEAN, «A Common Inheritance? An Examination of the Private International Law Tradition of the Commonwealth», RCADI, vol. 260, 1996, pp. 11-98. 


\section{Objeto de la prueba del Derecho extranjero}

32. Debe probarse el «Derecho extranjero». Por «Derecho extranjero» hay que entender el entero ordenamiento jurídico extranjero, comprendiendo todo tipo de normas jurídicas que lo integren y que sean aplicables al caso concreto: normas escritas, costumbre y demás reglas que sean Derecho objetivo —ad ex. jurisprudencia, principios generales del Derecho, equidad, etc.- (SAP Barcelona 12 noviembre 1999).

33. El art. 281.2 LEC sólo indica que hay que probar el contenido y la vigencia del Derecho extranjero. La pregunta surge espontánea: ¿es suficiente probar sólo ambos extremos, o es preciso probar, además, «otros aspectos» del Derecho extranjero?

La primera tesis (se debe probar, exclusivamente, el «contenido y vigencia» del Derecho extranjero), ha sido defendida por la SJS Comunidad Madrid 29 octubre 2003: inclusio unius exclusio alterius.

La segunda tesis es la preferida por el TS y parece más correcta (STS 13 enero 1887, STS 12 mayo 1887, STS 10 julio 1900, STS 12 julio 1904, STS 19 noviembre 1904, STS 30 junio 1962, STS 12 enero 1989, STS 7 septiembre 1990, STS 16 julio 1991, STS 25 enero 1999, STS 11 mayo 1989, STS 12 diciembre 1935, STS 23 octubre 1992, SAP Madrid 23 noviembre 2000, SAP Castellón 22 noviembre 2002, SAP Girona 31 marzo 2003). En efecto: se deben probar todos aquellos aspectos del Derecho extranjero que sean necesarios para que el tribunal español falle del modo más aproximado a como lo haría un tribunal de dicho Estado extranjero (STS 30 junio 1962, STS 5 noviembre 1971). Por ello, debe probarse a) el contenido del Derecho extranjero: el tenor literal de las normas extranjeras; b) la vigencia y existencia del Derecho extranjero, lo que es importante en relación con países de reciente creación y en casos de posible contradicción entre las Leyes de un país concreto y la Constitución de dicho país; c) la interpretación concreta de las normas del Derecho extranjero: ello incluye, en su caso, la prueba de la jurisprudencia extranjera que aplica e interpreta el Derecho extranjero; d) la aplicabilidad del Derecho extranjero al caso concreto. Resultado: si se prueba el Derecho extranjero de modo detallado, dicho Derecho extranjero no suscitará «la menor duda razonable a los tribunales españoles», como indica el TS (STS 11 mayo 1989, STS 25 enero 1999, STS 17 julio 2001, SAP Girona 27 mayo 2002). Una vez acreditado satisfactoriamente el Derecho extranjero aplicable al fondo del asunto, el tribunal español debe dar respuesta a las peticiones de las partes, necesariamente, de manera motivada y sobre la base del Derecho extranjero aplicable. Si resuelve el litigio mediante la aplicación del Derecho sustantivo español, la sentencia está viciada de «nulidad» (SAP Málaga 29 julio 2004).

\section{Carga de la prueba del Derecho extranjero}

34. La LEC establece que, como regla general, la prueba del Derecho extranjero se practica $a$ instancia de parte (art. 282 LEC). Pero también afir- 
ma que caben excepciones a dicha regla, porque el tribunal puede intervenir en la «aplicación» del Derecho extranjero (art. 281.2 LEC). Sin embargo, la LEC no precisa «en qué casos» y «con qué intensidad» puede intervenir el tribunal en la prueba del Derecho extranjero. Para resolver el problema, cabe distinguir varios grupos de casos.

35. a) Prueba del Derecho extranjero por las partes: «normas de conflicto meramente localizadoras». Cuando las normas de conflicto designan el Derecho extranjero con independencia, a priori, de su «contenido material», las partes deben probar el Derecho extranjero. Es cierto que la LEC $1 / 2000$ no indica «qué parte» debe hacerlo, demandante o demandado. En tal caso puede presumirse, como punto de partida, que ante la falta de indicación legal, valen las «reglas generales». De este modo, la parte interesada en la aplicación del Derecho extranjero deberá probarlo. Puede ser, por tanto, el demandante o el demandado. Dependerá del caso. Esta regla se justifica porque, visto que la aplicación del Derecho extranjero afecta a un «interés particular» y no a «intereses de la comunidad social», es justo que sean las partes las que asuman los costes de la prueba del Derecho extranjero (STSJ Andalucía Social 1 junio 2004). Así, la «parte interesada» en un «reenvío de retorno» (art. $12.2 \mathrm{Cc}$.), debe probar la norma de conflicto extranjera - que es también una norma de Derecho extranjero- (STS 15 noviembre 1996, SAP Tarragona 13 mayo 2004). El demandante debe probar el Derecho extranjero si basa en él su demanda; el demandado debe probar el Derecho extranjero si basa en él su contestación a la demanda (SAP Baleares 31 marzo 2004). El hecho de que el Derecho extranjero sea aplicable en virtud de una norma de conflicto contenida en un convenio internacional o Reglamento comunitario, no debe incidir en la aplicación del Derecho extranjero a instancia de parte, al menos si la norma de conflicto es «meramente localizadora» (SAP Alicante 18 noviembre 2003), pues las cuestiones de «prueba del Derecho extranjero» suelen quedar al margen de tales Convenios internacionales (T. C. HARTLEY ${ }^{20}$ ).

36. b) Prueba del Derecho extranjero por el tribunal: normas de conflicto que exigen la aplicación de oficio del Derecho extranjero. En ciertos casos, el legislador manifiesta un interés claro en que se aplique el Derecho extranjero. Ese interés debe prevalecer. Por ello, si las partes no prueban el Derecho extranjero, el tribunal está obligado a probar, de oficio, el Derecho extranjero. El coste de probar el Derecho extranjero lo asume el tribunal y el Estado porque se haya implicado un «interés sensible y general» que afecta a la «comunidad social». Los casos más relevantes en los que procede la

${ }^{20}$ T. C. HARTLEY, «Pleading and Proof of Foreign Law: The Major European Systems Compared», ICLQ, 1996, pp. 271-292. 
prueba de oficio del Derecho extranjero son los siguientes: (a) Derecho extranjero designado por normas de conflicto materialmente orientadas. Estas normas ordenan aplicar un concreto Derecho extranjero, precisamente, debido al contenido material de dicho Derecho extranjero. Con estas normas de conflicto, se defienden «intereses sensibles» — protección del menor, defensa del consumidor, del trabajador o del acreedor de alimentos, etc.-—; (b) Normas internacionalmente imperativas del Derecho extranjero (Eingriffsnormen). Defienden intereses estatales de primer orden, por lo que deben ser aplicadas de oficio por el tribunal español: ad ex. normas antitrust extranjeras.

37. c) Prueba del Derecho extranjero por el tribunal: imposibilidad de las partes de probar el Derecho extranjero. En ocasiones, las partes intentan probar el Derecho extranjero de buena fe y hacen todo lo posible al efecto, pero no consiguen probarlo. En tales casos, el tribunal está obligado a probar, de oficio, el Derecho extranjero, lo que puede hacer bien mediante una «ayuda» prestada a las partes para probar el Derecho extranjero, o incluso, mediante la realización de la «entera prueba» del Derecho extranjero (STC 10/2000 de 17 enero 2000, SAP Girona 7 junio 2004). Ejemplo: una mujer armenia solicitó el divorcio de su marido armenio, pero vista la situación bélica de su país, no pudo probar el Derecho extranjero. El TC indicó que el juez no debió desestimar la demanda de divorcio, sino que debía haber ayudado a la demandante a probar el Derecho extranjero (STC 10/2000 de 17 enero 2000, caso de los armenios). Si el tribunal no interviniera en estos casos, se vulneraría la tutela judicial efectiva (art. $24 \mathrm{CE}$ ). Pero mucho cuidado: para que esta «necesaria intervención del tribunal» se verifique, deben quedar claros estos extremos. Primero: la «necesaria intervención del tribunal» en estos casos no procede si la parte se encuentra en «en óptima disposición» para probar la Ley extranjera, pues en dicho supuesto, la parte, y sólo la parte, debe probar el Derecho extranjero (STSJ Madrid 26 febrero 2004), y si no lo hace, la pretensión de la parte debe ser desestimada. Segundo: debe quedar plenamente acreditado en el proceso, sin dudas razonables, que efectivamente, la prueba del Derecho extranjero resulta «imposible de facto» para la parte.

Los casos más frecuentes de «imposibilidad de prueba del Derecho extranjero por las partes» son los siguientes: (a) el país cuya Ley debe ser probada es un país muy lejano y/o está envuelto en conflictos bélicos u otras turbulencias sociales, lo que hace que, de hecho, los particulares tengan muchas dificultades para recabar información jurídica procedente de dichos países; (b) la parte no dispone de «recursos económicos suficientes» para costear una exitosa prueba del Derecho extranjero, por lo que, de hecho, la prueba del Derecho extranjero resulta imposible para dicha parte. Téngase en cuenta que el beneficio de justicia gratuita no cubre el pago a dos jurisconsultos extranjeros que acrediten el contenido del Derecho extranjero ni la traducción a lengua oficial española del texto legal extranjero (F. CALvo 
BABÍO $\left.{ }^{21}\right)$. Por ello, la «justicia gratuita» no garantiza que la parte obtenga «gratis» la prueba del Derecho. Pues bien, cuando la parte no dispone de recursos económicos suficientes, el tribunal debe probar el Derecho extranjero. Ello evita que el DIPr. opere como un «Derecho para ricos» que sólo funciona correctamente cuando la parte dispone de recursos económicos suficientes para probar el Derecho extranjero, discriminando de facto al litigante económicamente menos favorecido (SAP Girona 7 junio 2004).

\section{Consecuencias jurídicas en el caso de falta de alegación y/o prueba del} Derecho extranjero: las diferentes tesis

38. La LEC 1/2000 no ofrece respuestas a la cuestión que se plantea cuando un Derecho extranjero rige un litigio por mandato de las normas de conflicto españolas, pero las partes argumentan sus posiciones sobre el Derecho español y no invocan y/o no prueban el Derecho extranjero. Tampoco ofrece respuesta a un caso muy frecuente: siendo aplicable un Derecho extranjero, el demandante presenta su demanda fundada en el Derecho español, y el demandado se limita a contestar que el Derecho español no es aplicable, sino que lo es el Derecho extranjero, Derecho que el demandado no prueba (ya que estima que debe ser el demandante el que lo debe probar y no lo hizo). La doctrina española y la jurisprudencia española han ofrecido distintas tesis al respecto. Al menos cinco tesis se han vertido (tesis de la inadmisión de la demanda, tesis de la retroacción de actuaciones procesales, tesis de la aplicación de oficio del Derecho extranjero, tesis de la aplicación sustitutiva del Derecho material español y tesis de la desestimación de la demanda).

Algún autor ha escrito que la «solución» es acometer una reforma legislativa del sistema vigente ${ }^{22}$. Pero esta propuesta presenta diversos puntos débiles. En primer lugar, esta propuesta ignora que un «sistema de textura abierta» como el actualmente vigente en España proporciona soluciones más saludables para los particulares que un futurible «sistema rígido». En efecto: el primer sistema, bien encauzado, se puede adaptar sin problemas a la cambiante realidad social actual. Sin embargo, el segundo sistema exige que la realidad social se adapte a la Ley, lo que, como es evidente, no suele suceder. Afirmar que sólo un «sistema rígido y definido» de prueba del Derecho extranjero cumple con el principio de «seguridad jurídica» es una afirmación con soporte débil. Explicación: el principio de «seguridad jurídica» no impli-

${ }^{21}$ F. CALvo BABío, «Problemas para probar Derecho extranjero en procedimientos judiciales españoles», Iuris, n. 93, 2005, pp. 85-61.

${ }^{22}$ S. Álvarez GonZÁlez, «Aplicación judicial del Derecho extranjero: la desconcertante práctica judicial, los estériles esfuerzos doctrinales y la necesaria reforma legislativa», Diario La Ley, núm. 6287 de 4 julio 2005; ID., «Nota a STS, Sala 4. ${ }^{\text {a }}$, de 4 de noviembre de 2004», en REDI, vol. 57, 2005-I, pp. 357-359. 
ca «normas rígidas» (un sistema de textura abierta que evoluciona «por casos» gracias a la creación de soluciones por los tribunales está en perfecta sintonía con la seguridad jurídica). Además, ello revela la intención de pretender poner puertas al campo, lo que no es fácil, ni realista ni conveniente. Encapsular en normas «definidas» 0 «rígidas» la inmensa riqueza de matices que pueden presentar todos los casos en los que un Derecho extranjero debe ser aplicado por tribunales españoles es un esfuerzo más vano que el destino que, según el Capítulo XI de la Odisea de Homero, sufría Sísifo, condenado a empujar una enorme piedra a la cima de una altísima montaña para ver, instantes antes de alcanzar dicho punto, cómo la piedra caía y debía comenzar de nuevo el inútil trabajo. Es, sencillamente, imposible. Además, ello impediría avanzar a la jurisprudencia en la creación de «grupos de casos» y de «grupos de reglas» válidos para regular un problema tan complejo como la prueba del Derecho extranjero. En segundo lugar, esta postura es poco eficiente y poco práctica: el juez que tiene que aplicar Derecho extranjero debe resolver el caso y dictar una sentencia (art. 1.6 Cc.), por lo que le interesa saber qué intepretación debe dar al art. 281.2 LEC, y no si el precepto debe reformarse o no. Al juez español que debe aplicar un Derecho extranjero, las consideraciones de lege ferenda le pueden resultar sugerentes, pero seguro que le serán completamente inútiles. Por otro lado, confiar en las intenciones de reforma del legislador es como confiar en la lotería: puede ser que toque, pero lo más probable es que no toque y que la reforma no se lleve a cabo. Por ello, estas propuestas de lege ferenda relativas a la posible reforma del sistema vigente se quedan en estériles sugerencias doctrinales, vox clamantis in deserto que el legislador no parece propicio, afortunadamente, a escuchar. En tercer lugar, porque esta presunta «propuesta» es una falacia. En efecto: ante las posibles soluciones al problema de «qué hacer» si el Derecho extranjero no se prueba en el proceso, se opta por no dar ninguna solución. ¿Qué debe hacer el juez español que tiene que aplicar un Derecho extranjero si las partes no prueban el contenido del Derecho? Respuesta: pedir que se cambie la LEC (?). Pues bien, eso no es una respuesta. Eso es «eludir la cuestión», la famosa falacia a la que ARISTÓTELES dio el nombre de Ignoratio Elenchi («elusión del asunto») en su célebre obra Refutaciones Sofísticas. Se trata de la falacia preferida de los sujetos que desean evitar toda crítica, ya que al «no resolver la cuestión», su propuesta no puede ser analizada para ver si ofrece soluciones satisfactorias o no satisfactorias. Esta falacia consiste, por tanto, en evitar dar «respuestas directas» a «preguntas directas» y está conectada con otras falacias no menos profundas, como por ejemplo, con la célebre «falacia de los peces rojos» (se introducen elementos que distraen la atención del problema central: la reforma legal es «muy importante» y eso evita dar una respuesta directa al problema del quid juris en caso de falta de prueba del Derecho extranjero).

En fin, refutada la falacia, puede dirigirse la mirada a las propuestas realistas y auténticas que ofrecen soluciones útiles al problema que se suscita 
cuando el Derecho extranjero no ha sido alegado y/o probado; resulta preciso analizar las cinco tesis principales al respecto.

\section{A) TESIS DE LA INADMISIÓN DE LA DEMANDA}

39. Algunos autores indican que si las partes no alegan ni prueban el Derecho extranjero, la demanda debe ser inadmitida. Pero la inadmisión de la demanda sólo es posible en los casos previstos por las leyes procesales (STC 33/2002 de 11 febrero 2002). Y las leyes procesales españolas no contemplan como causa de rechazo de la demanda, la «falta de alegación y/o prueba del Derecho extranjero» (art. 403 LEC). Por tanto, esta primera tesis debe ser rechazada.

\section{B) TESIS DE LA «RETROACCIÓN DE ACTUACIONES» PROCESALES}

40. Esta tesis fue acogida por la SAP Baleares 9 octubre 2002. Consiste en que, cuando la parte no prueba el Derecho extranjero, procede, con arreglo al art. 429 LEC 2000, «retrotraer las actuaciones procesales» de modo que la parte presente su demanda con sujeción al Derecho extranjero aplicable, se practique prueba contradictoria sobre el Derecho extranjero y finalmente, se dicte nueva sentencia con arreglo al Derecho extranjero. La tesis es ingeniosa, pero también rechazable, porque el art. 429.1.II LEC está diseñado para casos en los que la prueba propuesta es insuficiente, y en este supuesto, la cuestión problemática es que la parte ha fundamentado jurídicamente su pretensión de modo incorrecto, no que la «prueba» presentada sea «insuficiente». El tribunal no tiene por qué hacer el trabajo de los abogados, que es fundamentar correctamente una pretensión desde el punto de vista jurídico y que son profesionales que cobran por su trabajo. Por ello, la tesis debe ser rechazada.

\section{C) Tesis de la APlicación De Oficio del Derecho eXtranjero}

41. Algunos autores indican que si las partes no alegan ni prueban el Derecho extranjero, el tribunal debe aplicar de oficio el Derecho extranjero designado por la norma de conflicto española, y luego dicho tribunal debe «imputar el coste» de la prueba practicada, a la parte que debió probar el Derecho extranjero (S. Álvarez GonzÁlez, J. C. Fernández Rozas / S. SÁNCHeZ LoRenZo, L. CARBALlo PiÑEIRO ${ }^{23}$ ).

${ }^{23}$ S. Álvarez GonZÁlez, «La aplicación judicial del Derecho extranjero bajo la lupa constitucional», REDI, 2002, pp. 205-223; J. C. FERnÁNDEZ RoZAS / S. SÁNCHEZ LoRENZO,

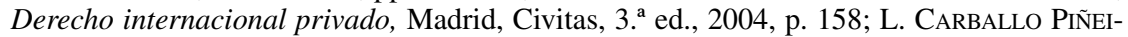
$\mathrm{RO}$, «El carácter imperativo de la norma de conflicto y la prueba del Derecho extranjero, Una relectura en clave procesal y constitucional», AEDIP, núm.1, 2001, pp. 483-503, esp. p. 496. 
42. La tesis encaja a la perfección con el carácter imperativo de las normas de conflicto españolas (art. 12.6 Cc.). En efecto, con esta tesis, el Derecho aplicable al fondo del asunto no será, nunca, distinto de aquel designado por la norma de conflicto española. Algún autor ha afirmado que la tesis de «la aplicación de oficio de la ley extranjera, (...) optimiza los valores constitucionales y, precisamente por esa mayor potenciación, debe ser generalizada»(A. ESPINIELLA MENÉNDEZ ${ }^{24}$ ). Y ¿qué argumentos se ofrecen para avalar tal afirmación? Pues ninguno. Simplemente se dice que las otras tesis rivales (la «aplicación sustitutiva de la Lex Fori» y la «desestimación de la demanda») son opciones que, como posibilidades en el marco legislativo (al margen de la Constitución) deben rechazarse porque la tesis de la aplicación de oficio del Derecho extranjero «optimiza los valores constitucionales». Pero cuidado: no se dice por qué optimiza los valores constitucionales, ni qué valores son ésos, ni por qué las otras tesis no optimizan dichos valores. Por ello, la afirmación de A. EsPINIELlA MENÉNDEZ constituye una falacia: es la falacia de la «afirmación gratuita», también llamada falacia de «Ipsedixtismo» o «falacia de la aseveración». En efecto: toda persona que afirma algo contrae dos compromisos. Debe probar lo que afirma sin irse por las ramas y debe, a tal fin, aportar pruebas suficientes, argumentos convincentes al efecto. Pues bien, el autor citado ni prueba nada ni aporta argumento alguno que respalde su afirmación. Se limita a decir que la tesis que defiende es «la mejor» porque «optimiza los valores constitucionales». Esta afirmación revela una opinión personal. Pero dicha opinión no se acompaña de fundamentos. Y, por supuesto, aunque se ponga mucha vehemencia en la afirmación, el entusiasmo no convierte algo en verdadero. Y por más que se repita, tampoco ese algo, por muy repetido que sea, resulta ser más verdadero. No está de más recordar que el mismísmo Tribunal Constitucional (ATC 422/2004 de 4 noviembre 2004) indica que la tesis de la desestimación de la demanda es una solución perfectamente adaptada a la Constitución Española, «razonada y razonable». Claro que el autor citado en ningún momento cita el ATC 422/2004 de 4 noviembre 2004 (quizás porque el TC dice lo que algunos no quieren escuchar). Ahora bien: los hechos son tozudos. El ATC 422/2004 de 4 noviembre 2004 existe, está ahí (puede consultarse en $<$ www.tribunalconstitucional.es $>$ ). El aparato verbal de retórica utilizado por el autor citado no es más que un vestido de «pseudoprofundidad». Se realizan afirmaciones aparentemente grandilocuentes relacionadas con la «optimización de los valores constitucionales» y con el rechazo de «disquisiciones entre la naturaleza procesal o sustantiva del problema» y se emplean guarismos matemáticos en la argumentación jurídica. La utilización de toda esta parafernalia pseudoprofunda es una «cortina de humo» cuyos obje-

${ }^{24}$ A. Espiniella MenÉnDEZ, «Nota a STC Sala 2. ${ }^{\text {a }}$ núm. 172/2004 de 18 octubre 2004», REDI, 2005, vol. 57, pp. 344-349, esp. p. 346. 
tivos son bien claros: esconder al lector interesado en el tema datos muy relevantes (el ATC 422/2004 de 4 noviembre 2004 no existe para este autor), atacar la constitucionalidad de una tesis (tesis de la desestimación de la demanda), cuyo ajuste con la CE 1978 ha sido expresamente declarado por el TC en dicho Auto, y atacar la posición de los autores que, como los que firman este trabajo, defienden una solución al problema que es perfectamente legítima tanto en términos de legalidad ordinaria como en términos de «optimización de los valores constitucionales». Todo ello sin olvidar que «el Derecho no es aritmética» (M. VIRGÓs SORIANO ${ }^{25}$ ), por lo que «traducir a números» las argumentaciones jurídicas resulta profundamente inadecuado.

En el estadio actual del DIPr. español, la tesis de la aplicación de oficio del Derecho extranjero es una tesis equivocada. Y ello por varios motivos.

43. Primero. La tesis no respeta el «reparto de la carga de la prueba» realizado por el art. 282 LEC. En España, en el marco del proceso civil, las pruebas se practican «a instancia de parte». Lo dice el art. 282 LEC. Y este precepto se aplica, sin duda alguna, a la prueba del «Derecho extranjero». Es cierto que tal regla general experimenta ciertas inflexiones relativas a la prueba del Derecho extranjero, inflexiones a las que alude el art. 281.2 LEC («pudiendo valerse el tribunal de cuantos medios de averiguación estime necesarios para su aplicación [se refiere a la aplicación del Derecho extranjero]»). Pero la intervención del tribunal en este sentido, aunque puede ser «amplia» o «expansiva» no puede alterar el principio de base, en los «casos normales». De este modo, las pruebas (también la del Derecho extranjero) se practican cuando las proponen las partes, y no en caso contrario. El tribunal no puede ni debe relevar a las partes de lo que a éstas incumbe. Pero es que, además, esta tesis confunde las posibilidades del tribunal en cuanto a la «prueba del Derecho extranjero» y en cuanto a la «alegación del Derecho extranjero». Efectivamente: incluso aunque se interpretara el art. 281.2 LEC en un sentido de «máxima expansión» que permitiera al tribunal proceder a la prueba, no solicitada por las partes, del Derecho extranjero (interpretación que no parece compartible), ello no resuelve el problema, porque si una parte ha basado sus posiciones jurídicas en el Derecho sustantivo español cuando debía hacerlo con arreglo a un Derecho extranjero, el tribunal estaría «alterando» las posiciones jurídicas de las partes, estaría «corrigiendo los defectos jurídicos» de la demanda, y no simplemente supliendo problemas prácticos de «prueba» del Derecho extranjero. Es decir, el tribunal estaría alterando los «fundamentos jurídicos» presentados por la parte que debía haber fundado su pretensión en el Derecho extranjero (operación no permitida por el art. 281.2 LEC), algo sobre lo que se volverá más adelante.

${ }^{25}$ M. Virgós Soriano, «Las cosas y los derechos reales», en J. D. GonZÁlez CAmpos y OTROS, Derecho internacional privado parte especial, 6. ${ }^{\mathrm{a}}$ ed. revisada, 1995, p. 270. 
El reparto de la carga de la prueba que lleva a cabo el art. 282 LEC diferencia al sistema español de DIPr. de otros sistemas extranjeros de Derecho internacional privado que parten del principio opuesto, esto es, que indican que la prueba del Derecho extranjero se llevará a cabo de oficio por el tribunal. En tal sentido, vid. art. 16 Ley federal suiza de Derecho internacional privado de 1987; art. 14 Ley italiana de Derecho internacional privado de 1995; arts. 3 y 4 Ley austríaca de Derecho internacional privado de 1978; art. 15.1 Código belga de Derecho internacional privado de 2004. Se puede discutir, por supuesto, si el «principio básico» seguido en Derecho internacional privado español es más o menos conveniente que el principio básico seguido en estos países. Pero no parece muy correcto discutir cuál ese principio básico en Derecho internacional privado español. En suma, en Derecho internacional privado español, el tribunal no tiene por qué hacer el trabajo de las partes asumiendo el coste económico, de recursos y de tiempo, que comporta la prueba de un Derecho extranjero, especialmente cuando los intereses en juego son «intereses particulares» (SAP Guipúzcoa 28 septiembre 2004).

44. Segundo. La tesis vulnera el art. 218.1.II LEC, y con ello, el principio de congruencia de la sentencia, el principio dispositivo, el principio de justicia rogada y la conformación del «objeto del proceso». En efecto, el tribunal no puede decidir el caso sobre «fundamentos de Derecho» distintos a los que las partes hayan hecho valer. Si las partes no invocan ni posteriormente prueban el Derecho extranjero cuando les corresponde hacerlo, el caso no puede fallarse con arreglo al Derecho extranjero, porque si así se hiciera, se vulneraría flagrantemente el art. 218.1.II LEC. En efecto, ¿por qué tiene el tribunal que decidir el caso sobre «fundamentos jurídicos» que no han sido esgrimidos por unas partes procesalmente «poco diligentes» asesoradas, por lo visto, por abogados que no saben fundamentar correctamente las pretensiones de sus clientes? Si las partes argumentan incorrectamente -lo que sucede cuando argumentan sobre el Derecho sustantivo español y no sobre el Derecho extranjero que debe regir el caso-, el tribunal no tiene por qué «hacer el trabajo» de una parte cuyos abogados no quieren o no saben fundamentar correctamente una pretensión jurídica. El art. 218.1.II LEC prohíbe expresamente una actuación del tribunal en dicho sentido. Y como se ha dicho antes, el art. 281.2 LEC puede servir de plataforma legal para potenciar una actitud más intervencionista del tribunal en orden a la «prueba procesal del Derecho extranjero», pero no puede servir de argumento para que el tribunal «rehaga» los planteamientos jurídicos de las partes.

45. Tercero. Es una tesis poco práctica, porque si el tribunal prueba el Derecho extranjero con la intención de «imputar su coste a las partes», nada impide al actor la «renuncia a la acción ejercitada» o al «derecho en que funde su pretensión» (art. 20.1 LEC), y nada impide tampoco al actor el «desistimiento» (art. 20.2 y 3 LEC), con lo que el tribunal habrá probado un Derecho extranjero pero no podrá imputar su «coste» a ninguna de las partes. 
46. Cuarto. Es una tesis que puede provocar indefensión y que, por tanto, puede vulnerar el art. $24 \mathrm{CE}$ y el derecho constitucional a la «tutela judicial efectiva». En efecto: si ambas partes argumentan sobre el Derecho español y el tribunal, sin embargo, falla con arreglo al Derecho extranjero, las partes pueden quedar jurídicamente «sorprendidas». Como escribe L. CARRILlo Pozo, «la intempestiva aplicación de un ordenamiento que no es español puede provocar sorpresa y por ende indefensión en la otra parte» ${ }^{26}$. Las partes deben saber en qué términos se mueve el debate procesal. Y cuidado: el debate procesal lo fijan las partes, el demandante en su demanda y el demandado en su contestación a la demanda. El tribunal, por supuesto, debe fallar el caso sólo con arreglo a las normas jurídicas que sean «objetivamente aplicables». Pero no puede «dar la razón» al demandante o al demandado mediante la aplicación de «argumentos jurídicos» que las partes no hayan hecho valer en el proceso.

47. En suma, esta tesis no respeta el reparto de la carga de la prueba fijado en la LEC, vulnera el principio de congruencia de la sentencia, violenta indebidamente el principio dispositivo y el principio de Justicia rogada que rigen y vertebran el proceso civil, no respeta el principio de congruencia de la sentencia ni tampoco la conformación del objeto del proceso, raya en la indefensión de las partes y además, es una tesis es tan poco práctica, que los litigantes «avispados», que no son pocos, pueden burlarla con pasmosa facilidad.

\section{D) Tesis DE LA APLiCACiÓN SUSTITUTIVA DEL DeRECHO MATERIAL ESPAÑOL}

48. La «tesis de la aplicación sustitutiva del Derecho material español» sostiene que si la parte argumenta, exclusivamente, basándose en el Derecho español, y no alega ni prueba el Derecho extranjero al que remite la norma de conflicto, es aplicable, entonces, el Derecho material español (Back To Lex Fori Rule).

49. La tesis se edifica sobre varios fundamentos, que son insistentemente remarcados por los muchos seguidores de esta tesis.

Primero. La Lex Fori presenta una «competencia general y residual» para regular «todo supuesto de Derecho privado». El argumento fue ya esgrimido hace más de cien años por el gran jurista francés E. BARTIN y fue seguido por el maestro galo $\mathrm{H}$. BATIFFOL y por otros ilustres autores del vecino país transpirenaico ${ }^{27}$. Por ello, según esta tesis, ante la falta de la «regla espe-

${ }^{26}$ L. CARriLlo Pozo, «Alegación y prueba del Derecho extranjero en el ámbito laboral y tutela judicial efectiva», Rev. Esp. Dcho. Trabajo, núm. 111, mayo-junio 2002, pp. 451473, esp. p. 467.

${ }^{27}$ E. BARTIN, Principes de Droit international privé, París, Domat Montchrestien, 19301932-1935, p. 409 ; P. MAYER / V. HeuZÉ, Droit international privé, París, Montchrestien, 8. ${ }^{a}$ ed., 2004, pp. 135-136 y 144-145 ; H. BatifFol / P. LAGARDE, Droit international privé,

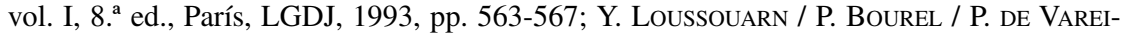

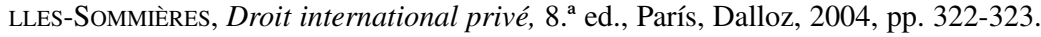


cial», —aplicación del Derecho extranjero-, se vuelve a la «regla general», que es la aplicación del Derecho del país cuyos tribunales conocen del asunto (Lex Fori).

Segundo. Si el Derecho extranjero no se alega ni prueba, debe aplicarse el Derecho sustantivo español porque sólo así se evita la «denegación de Justicia» y se proporciona una «respuesta sobre el fondo» al litigio. Por tanto, esta tesis respeta escrupulosamente el derecho a la «tutela judicial efectiva» (art. $24 \mathrm{CE}$ ).

Tercero. El Derecho extranjero es un «hecho procesal». No es «Derecho». Y no se puede considerar como «Derecho», porque si así fuera, se estarían aplicando, en España, los «mandatos soberanos» dictados por un legislador extranjero, lo que comportaría una lesión intolerable de la Soberanía española. Como el Derecho extranjero es un «hecho procesal», lo deben probar las partes interesadas. Y si no se alega ni se prueba el Derecho extranjero, éste «desaparece» del proceso: simplemente no existe. Por ello, el tribunal fallará el caso prescindiendo del «Derecho extranjero» (que se considera un «hecho no alegado al proceso»), es decir, fallará con arreglo al Derecho sustantivo español (Back To Lex Fori Rule).

50. Esta tesis es la más extendida en la práctica jurídica española. Al respecto pueden subrayarse varios datos.

En primer lugar, esta tesis es la preferida por la Sala Primera del TS. Esta Sala acogió la tesis que se comenta, ya antes de la promulgación del Código Civil en 1889. Y después de la promulgación del Código Civil en 1889, la Sala Primera del TS siguió sosteniendo la misma tesis. Y después de 1974, fecha en la que se introdujo en el Código Civil el art. 12.6.II, precepto que abordaba parcialmente el asunto, también siguió la Sala Primera del TS aferrada a su tesis tradicional. Aunque todavía la Sala Primera del TS no ha tenido ocasión de pronunciarse sobre la aplicación del hoy vigente art. 281.2 LEC 1/2000, dicha Sala Primera del TS ya ha dejado caer, obiter dicta, que el régimen recogido en el dicho precepto no altera para nada la solución que dicha Sala viene aplicando desde mediados del siglo XIX. Los pronunciamientos jurisprudenciales que siguen esta tesis son innumerables: vid. ad ex. STS 21 junio 1864, STS 20 marzo 1877, STS 13 enero 1885, STS 26 mayo 1887, STS 28 enero 1896, STS 7 noviembre 1896, STS 19 noviembre 1904, STS 1 febrero 1934, STS 9 enero 1936, STS 17 julio 1937, STS 29 septiembre 1956, STS 16 diciembre 1960, STS 30 junio 1962, STS 6 junio 1969, STS 5 noviembre 1971, STS 12 enero 1989, STS 11 mayo 1989, STS 21 junio 1989; STS 23 marzo 1994; STS 7 septiembre 1990; STS 25 enero 1999, STS 7 septiembre 1990, STS 10 diciembre 1990, STS 16 julio 1991, STS, 17 diciembre 1991, STS 23 octubre 1992, STS 31 diciembre 1994, STS 15 noviembre 1996, STS 25 enero 1999, STS 9 febrero 1999, STS 5 junio 2000, STS 13 diciembre 2000, STS 17 julio 2001, STS 5 marzo 2002, STS 29 diciembre 2003, STS 2 julio 2004, STS 10 junio 2005. Más de cien años con la misma tesis: bad habits die hard. 
En segundo lugar, esta tesis es seguida, en la actualidad, por muchas Audiencias Provinciales españolas. La razón radica en que, de este modo, las Audiencias evitan recursos de casación ante el TS. Los ejemplos son muy numerosos. Entre los más recientes, cabe citar: SAP Madrid 23 noviembre 2000, SAP Girona 19 mayo 2000, SAP Sevilla 9 enero 2002, SAP Castellón 22 noviembre 2002, SAP Girona 27 mayo 2002, SAP Barcelona 30 abril 2002, SAP Alicante 22 noviembre 2002, SAP Málaga 11 septiembre 2002, SAP Alicante 18 noviembre 2003, SAP Las Palmas 30 julio 2003, SAP SC Tenerife, Sec. 3. ${ }^{\text {a }}$, 28 junio 2004, SAP Almería 28 junio 2004, SAP Tenerife 13 abril 2004, SAP Alicante 2 marzo 2004, SAP Barcelona 19 enero 2004, SAP Almería 28 junio 2004, Auto AP Vizcaya 25 junio 2004, SAP Vizcaya 13 mayo 2004, SAP Almería 9 noviembre 2004, SAP Barcelona 15 junio 2005, SAP Lleida 15 junio 2005, SAP Asturias 1 septiembre 2005, SAP Alicante 12 mayo 2005, STSJ Com. Valencia 16 mayo 2005, etc.

En tercer lugar, esta tesis es apoyada por ciertos autores, que defienden que el sistema español de Derecho internacional privado debe operar como un Fakultatives Kollisionsrecht o Facultative Choice-Of-Law System (M. Virgós Soriano / F. J. GARCIMARTín AlfÉREZ ${ }^{28}$ ): el Derecho extranjero al que remiten las normas de conflicto sólo se aplica si las partes lo hacen valer, lo alegan y lo prueban. Por tanto, tales partes son libres de «prescindir» de las normas de conflicto españolas (y consiguientemente son libres de «prescindir del Derecho extranjero»). Las partes pueden indicar al tribunal que desean que el litigio se rija por el Derecho sustantivo español. En el fondo, estos autores «flexibilizan» el sistema de Derecho internacional privado, porque la tesis del Facultative Choice-of-Law System resulta un «escape» muy oportuno para los casos en los que el punto de conexión de la norma de conflicto ofrece un resultado poco adaptado a las necesidades de los particulares. Ejemplo: el art. 107.2 Cc. indica que el divorcio contencioso entre dos cónyuges turcos debe regirse por la Ley turca. Pero si ninguno de los cónyuges está mínimamente interesado en la aplicación de la Ley turca, ¿qué sentido tiene obligar a las partes a alegar y probar el Derecho turco para obtener su divorcio en España? Ninguno. Con un Facultative Choice-of-Law System, las partes quedan «liberadas» de una norma de conflicto torpe y poco eficiente: las partes alegan el Derecho español y fundan en él sus pretensiones y nadie se acuerda del Derecho turco. Ello sucede en relación con normas de conflicto mal redactadas, normas de conflicto que siguen criterios erróneos de política legislativa, y que no prestan atención a los problemas reales de los particulares en el contexto internacional. El «ejemplo estrella» es el citado art. 107.2 Cc. (en su redacción dada por la Ley orgánica 11/2003, de 29 de septiembre, de medidas concretas en materia de seguridad ciudadana, violen-

${ }^{28}$ M. Virgós Soriano / F. J. Garcimartín AlfÉRez, Derecho procesal civil internacional. Litigación internacional, Civitas, Madrid, 2000, pp. 368-371. 
cia doméstica e integración social de los extranjeros, en BOE núm. 234 de 30 septiembre 2003), precepto que señala la Ley aplicable al divorcio y la separación judicial, un artículo que revela los muy escasos conocimientos del legislador sobre el Derecho internacional privado ${ }^{29}$.

51. Sin embargo, la «tesis de la aplicación sustitutiva del Derecho material español» es rechazable por varios motivos.

52. Primero. La tesis vulnera el «carácter imperativo» de las normas de conflicto recogido en el art. 12.6 Cc.: cuando un Derecho extranjero debe regular una controversia, tal Derecho es el «único Derecho aplicable», y el Derecho español nunca puede regular tal controversia.

53. Segundo. La tesis comporta una altísima inseguridad jurídica. Vulnera el art. 9 CE. Con esta tesis no se puede saber, a priori, cuál es el Derecho aplicable a una situación privada internacional (L. F. CARRILLO POZO ${ }^{30}$ ).

54. Tercero. La tesis favorece conductas estratégicas y antijurídicas de las partes, que, sabiendo que una situación se rige por un Derecho extranjero, invocan el Derecho español como aplicable. Ello es inaceptable, porque el «fundamento jurídico» de una pretensión es «objetivo», lo quieran o no las partes y digan lo que digan las partes en sus demandas o contestaciones, de modo que tal «fundamento jurídico» no puede ser «alterado» por mera conveniencia de las partes. Ejemplo: si procede la adquisición de propiedad por usucapión es porque así lo prevé un determinado precepto del Código Civil alemán, al que remite el art. 10. Cc. Pues bien: ese concreto precepto del Derecho alemán, y ninguno otro, es el «fundamento objetivo de la pretensión». Por tanto, no puede acogerse la pretensión de un sujeto que indica al tribunal, en su favor, la aplicación de otro precepto del Código civil español en vez del concreto precepto del Código civil alemán, que es el único precepto objetivamente aplicable al litigio.

55. Cuarto. No es cierto que el «Derecho Privado material interno español» presente una «vocación general» para regular todos los casos de Dere-

${ }^{29}$ A. L. Calvo Caravaca / J. Carrascosa González, Derecho internacional privado, vol. II, 6. ${ }^{\text {a }}$ ed., Ed. Comares, Granada, 2005, pp. 85-112; ID., «El divorcio internacional y el nuevo art. 107.2 del Código Civil», La Ley, 24 mayo 2004, pp. 1-9 y La Ley, 25 mayo 2004, pp. 1-7.; B. CAMPUZANo DíAZ, «Consideraciones acerca de la reforma del art. $107 \mathrm{Cc}$.», en AA.VV., El Derecho de familia ante el siglo XXI: aspectos internacionales, Colex, Madrid, 2004, pp. 177-193; M. ${ }^{a}$ P. Diago DiAGo, «La nueva regulación española de las crisis matrimoniales ante el impacto de la multiculturalidad», en AA.VV., El Derecho de familia ante el siglo XXI: aspectos internacionales, Colex, Madrid, 2004, pp. 271-294.

${ }^{30}$ L. CARriLlo Pozo, «Alegación y prueba del Derecho extranjero en el ámbito laboral y tutela judicial efectiva», Rev. Esp. Dcho. Trabajo, núm. 111, mayo-junio 2002, pp. 451473; ID., «Una doctrina constitucional sobre alegación y prueba de la Ley extranjera», Aranzadi Social, 2003, núms.7-8, pp. 53-84. 
cho Privado. El Derecho Privado material español —el Derecho civil, mercantil y laboral español-, fue diseñado por el legislador para ser aplicado sólo en casos «internos» (Purely Internal Situations), no para ser aplicado en casos «internacionales» (Cases with Cross-Border Implications), por lo que el Derecho material interno español no constituye una «regla general» aplicable a «todo supuesto de Derecho Privado» ${ }^{31}$.

56. Quinto. No es cierto que, cuando el Derecho extranjero aplicable no ha sido alegado ni probado, la «única manera» de garantizar una «respuesta sobre el fondo del asunto» sea aplicar el Derecho sustantivo español. Esta afirmación es totalmente falsa. Como es evidente, la desestimación de una pretensión cuando ésta contiene un fundamento jurídico erróneo o inexistente, es una «auténtica respuesta sobre el fondo» que garantiza perfectamente la «tutela judicial efectiva» (art. $24 \mathrm{CE}$ ). O en otras palabras, tomadas de la doctrina del TC: una sentencia que desestima las pretensiones del actor, por estar erróneamente fundamentadas en Derecho, es una sentencia perfectamente «fundada en Derecho». Como expresa la STC 10/2000, de 17 de enero de 2000, «...lo relevante no es que las pretensiones de la parte se hayan desestimado, pues en multitud de ocasiones ha dicho este Tribunal que el derecho fundamental a la tutela judicial efectiva no garantiza un pronunciamiento acorde con las pretensiones de la parte, sino una resolución fundada en Derecho (...) Lo decisivo es que la desestimación de la pretensión de la parte sea la consecuencia de la previa conculcación por el propio órgano judicial de un derecho fundamental del perjudicado, encubriéndose tras una aparente resolución judicial fundada en Derecho una efectiva denegación de Justicia». En tal sentido, vid. también STC 55/1993, de 15 de febrero 1993, ATC 148/1999, de 14 de junio 1999, SSTC 1/1996, de 15 de enero 1996, STC 217/1998, de 16 de noviembre 1998, STC 183/1999, de 11 de octubre 1999. El ATC 422/2004 de 4 noviembre 2004 demuestra que esta tesis no es la única «constitucionalmente ajustada».

57. Sexto. No es cierto que la aplicación de un Derecho extranjero en España comporte un «atentado contra la Soberanía española». Este argumento es, hoy en día, como explica magistralmente H. MUIR-WATT ${ }^{32}$, totalmente insostenible: aplicar un Derecho extranjero en otro país en calidad de «Derecho», no lesiona en absoluto la Soberanía de ese otro país, pues el Derecho extranjero no es Derecho «vigente» en otro país, pues tal Derecho extranjero sólo «se aplica» en otro país. Este argumento, hoy, no convence, especial-

${ }^{31}$ A. L. Calvo Caravaca / J. Carrascosa González, Derecho internacional privado,

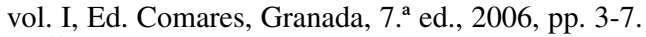

${ }^{32}$ H. MuiR-WatT, «Loi étrangère», Dalloz Droit international, 2. ${ }^{a}$ ed., 1998; A. L. CALvo Caravaca / J. Carrascosa González, Derecho internacional privado, volumen I, 7. ${ }^{a}$ ed., Comares, Granada, 2006, pp. 241-280. 
mente, cuando en la actualidad se admite que el Derecho internacional privado resuelve problemas atinentes al interés de los «particulares», no al interés de los «Estados».

58. En conclusión, esta tesis decimonónica genera inseguridad jurídica, no tiene soporte constitucional, es contraria al principio dispositivo que inspira el proceso civil y laboral, propicia las maniobras antijurídicas, desconoce el carácter y función de las normas de conflicto, y sus presuntos «argumentos de fondo» son falsos, vacíos, caducos, trasnochados, obsoletos y en muchas ocasiones, constituyen puros sofismas y dogmáticas declaraciones de principios que no se corresponden con la realidad.

\section{E) Tesis DE LA Desestimación DE LA DEMANDA}

\section{a) Exposición y fundamentos de la tesis}

59. Esta tesis indica que, en el caso de un litigio que debe regirse por un Derecho extranjero, si una parte argumenta, exclusivamente, sobre el Derecho español y no invoca ni prueba el Derecho extranjero, el tribunal debe dictar una sentencia que desestime la pretensión de dicha parte. Esta tesis es la más correcta, por varios motivos.

60. Primero. Porque en circunstancias normales (especialmente en presencia de normas de conflicto tradicionales «meramente localizadoras»), el tribunal no puede aplicar de oficio el Derecho extranjero (vid. art. 282 y 218.1.II LEC), pero tampoco puede aplicar el Derecho sustantivo español (se lo prohibe el art. 12.6 Cc., precepto que, debe recordarse, sigue plenamente vigente).

61. Segundo. Porque el art. 218.1.II LEC indica que el tribunal no puede resolver el caso acudiendo a «fundamentos de Derecho distintos a los que las partes han querido hacer valer»: si una parte argumenta su pretensión sobre el Derecho español y el Derecho aplicable era un Derecho extranjero, el tribunal no debe hacer el trabajo que corresponde al abogado de dicha parte (trabajo que dicho abogado no hizo correctamente). Este aspecto merece un análisis más detallado que se lleva a cabo más adelante.

62. Tercero. Porque de este modo se evita la «maniobra antijurídica» de permitir que las partes hagan aplicable el Derecho español «a voluntad» cuando el caso debe regirse por un Derecho extranjero (STSJ Canarias 19 septiembre 2003, STSJ Madrid Social 31 mayo 2004). Ello debe ser evitado, porque el fundamento jurídico de toda pretensión es «objetivo»: las partes no lo pueden «alterar». Ejemplo: si un divorcio contencioso entre cónyuges armenios se rige por el Derecho armenio (art. 107.2 Cc.), el fundamento jurídico de la demanda de divorcio debe encontrarse en el Derecho armenio, y nunca podrá sustentarse dicha demanda de divorcio en el Derecho español, 
aunque lo quieran las partes o exclusivamente el demandante, y se lo supliquen al tribunal y aunque resulte «más cómodo» tanto para las partes como para el tribunal. Las partes no pueden «alterar el fundamento objetivo» de la demanda de divorcio. Y el tribunal tampoco. Como muy correctamente expresó la STS, Social, 19 febrero 1990, la «falta de alegación y prueba [de la Ley extranjera] no puede conducir (...) a la aplicación de la ley española, pues ello equivaldría al absurdo de sancionar la omisión de prueba deliberadamente querida de la norma extranjera, con la aplicación de la ley española, cuando se considerase que ésta era más beneficiosa». También abunda en esta idea, con corrección extrema, la STS, Social, 22 mayo 2001: «lo que sucede es que, si el Derecho aplicable es el extranjero, la parte que formula la pretensión tiene que alegar y probar ese Derecho para que su pretensión sea acogida».

63. Cuarto. Porque esta tesis refuerza la seguridad jurídica (art. 9.3 CE): el Derecho aplicable nunca será un Derecho distinto al Derecho designado por la norma de conflicto. Ejemplo: si un contrato de trabajo a desarrollar en Inglaterra se rige por el Derecho inglés, conforme al cual se han pagado los salarios y se han prestado los servicios, resulta obvio, lógico, congruente y justo que si se plantea ante los tribunales españoles un pleito por presunto «despido improcedente» del trabajador, la cuestión litigiosa se decida con arreglo al Derecho inglés y no con arreglo a ningún otro ordenamiento jurídico estatal. Aplicar el Derecho español a este pleito rompería toda la seguridad jurídica que las normas de conflicto proporcionan.

64. Quinto. Porque esta tesis no supone ninguna «denegación de Justicia» ni por tanto, tampoco supone ninguna vulneración de la «tutela judicial efectiva» recogida en el art. $24 \mathrm{CE}$. En efecto: la desestimación de la demanda (Dismissal of the Case) es, en estos casos, una «respuesta motivada» a la pretensión de las partes. Únicamente significa que la demanda no ha sido correctamente planteada desde un punto de vista jurídico: las partes debían fundamentar sus posiciones en el Derecho extranjero y no en el Derecho español. Por tanto, la desestimación de la demanda es, en estos casos, una respuesta plenamente fundada y motivada, pues toda demanda cuyo fundamento jurídico sea irreal, inexistente o incorrecto, debe ser desestimada (ATC 422/2004 de 4 noviembre 2004 y Voto Particular STS, Social, 4 noviembre 2004). El TC indica, expresamente, que la «desestimación de una pretensión» cuando ésta se construye sobre un fundamento jurídico equivocado, irreal, erróneo o inexistente, es una «respuesta sobre el fondo» que encaja de modo perfecto con la «tutela judicial efectiva» exigida por el art. 24 CE. Es decir: una sentencia que desestima las pretensiones de las partes, por estar tales pretensiones erróneamente construidas en Derecho, es una sentencia «fundada en Derecho» (vid. STC 10//2000, de 17 de enero de 2000, STC 55/1993, de 15 de febrero 1993, ATC 148/1999, de 14 de junio 1999, SSTC 1/1996, de 15 de enero 1996, STC 217/1998, de 16 de noviem- 
bre 1998, STC 183/1999, de 11 de octubre 1999). Este aspecto será tratado más adelante con mayor detalle.

65. Una vez desestimada la demanda, se abre un profundo interrogante: ¿debe permitirse que el actor reitere su misma pretensión pero con una fundamentación jurídica basada ahora en un Derecho extranjero? La cuestión es muy dudosa porque el art. 400 LEC se presta a diversas interpretaciones. Parece aconsejable no «cerrar la puerta» totalmente a un nuevo proceso, de modo que, una vez desestimada la demanda incorrectamente fundamentada (se alegó y se fundamentó en Derecho español, Derecho que no puede aplicarse al caso), el actor puede volver a instar su pretensión fundándose en el Derecho extranjero aplicable según las normas de conflicto españolas. El art. 400 LEC no debería impedir «volver a plantear la cuestión» en este caso, porque al cambiar los «fundamentos jurídicos» de la demanda, se altera la «causa de pedir»y el «objeto del proceso». Por ello, la «cosa juzgada» del primer pleito no debería impedir volver a plantear un segundo pleito con un objeto diferente, como indica la STC 177/1985 de 18 diciembre 1985, pues en dicho caso, se altera el fundamento jurídico que sustenta la acción ejercitada, de modo que la causa petendi es ahora distinta. Así lo admite expresamente, con fundados argumentos, la SAP Castellón 7 abril 2005.

66. Esta tesis de la «desestimación de la demanda» cuenta con varios apoyos en la práctica española de Derecho internacional privado.

En primer lugar, ha sido una tesis defendida por numerosos tribunales inferiores, antes y después del vigente art. 281.2 LEC: SAP Bilbao 31 junio 1991, SAP Alicante, Sec. 4. a 4 octubre 1995, SAP Murcia 11 diciembre 1995, SAP Málaga 17 mayo 1995, STSJ Madrid Social 7 julio 1997, SAP Barcelona 15 septiembre 1998, SAP Alicante 27 noviembre 1998, SAP Madrid 28 septiembre 2000, SAP Valencia 3 febrero 1999, SAP Guadalajara 13 mayo 2000, SAP Castellón 23 abril 2002, STSJ Madrid Social 11 diciembre 2002, STSJ Galicia Social 31 octubre 2002, STSJ Madrid Social 31 mayo 2002, SJSocial Com. Madrid 11 noviembre 2002, STSJ Madrid 27 mayo 2002, SAP Madrid 26 marzo 2003, STSJ Canarias 19 septiembre 2003, SJS Com. Madrid 29 octubre 2003; SAP Barcelona 10 mayo 2004, SAP SC Tenerife, Sec. 4. a 28 junio 2004, SAP Vizcaya 6 abril 2004, SAP Castellón 7 abril 2005.

En segundo lugar, es la tesis que defendió la Sala de lo Social del TS desde 2001 (STS, Social, 22 mayo 2001 y STS, Social, 25 mayo 2001). Este dato reviste una importancia crucial, porque, por primera vez en la Historia del Derecho internacional privado en España, una Sección del TS se alejó radicalmente de la caduca y decimonónica tesis centenaria seguida con ojos cerrados por la Sala Primera del TS («aplicación sustitutiva del Derecho material español»). Por desgracia, la STS, Social, 4 noviembre 2004, vuelve atrás y abandona dicha jurisprudencia, inclinándose, erróneamente, a favor de la tesis de la «aplicación subsidiaria del Derecho español», debido a una 
equivocada y sesgada lectura de la jurisprudencia del TC. La mencionada sentencia cuenta con dos votos particulares, ambos muy acertados, cuya lectura constituye un deleite para todo jurista y que ponen en cuarentena el fallo de la citada STS, Social, 4 noviembre 2004. Tales votos particulares demuestran, con meridiana claridad, que el fallo de la STS, Social, 4 noviembre 2004, carece de todo sustento legal, ya que se apoya en meros «argumentos de autoridad» (la solución correcta es la aplicación sustitutiva del Derecho español, pero no porque sea la «más ajustada a Derecho», sino simplemente, «porque lo dice el TC»), argumentos de autoridad que, además, son totalmente falsos (el TC no afirma lo que la STS, Social, 4 noviembre 2004, dice que el TC afirma: donde hay molinos de viento, la Sala de lo Social del TS ve gigantes). Esta actitud de «marcha atrás» en la jurisprudencia de la Sala de lo Social del TS se explica por el temor de dicha Sala a ser censurada por un futuro pronunciamiento del TC (la Sala de lo Social del TS «corrige»su anterior y acertada doctrina por temor a ser «desautorizada» en el futuro por el TC). Es un argumentum ad baculum «preventivo», otro sofisma tan falaz como el «argumento de autoridad».

En tercer lugar, esta tesis fue apoyada por el Ministerio Fiscal en el caso resuelto por la STC 172/2004 de 18 octubre 2004 y por el ATC 422/2004 de 4 noviembre 2004, que expresamente defendió el ajuste constitucional de esta tesis.

En cuarto lugar, es una tesis defendida, desde 2000, por A. L. CALvo CARAVACA / J. CARrascosa GonzÁlez ${ }^{33}$ y posteriormente por P. ABARCA JUNCO / M. GÓMEZ JENE ${ }^{34}$.

En quinto lugar, ha sido una tesis defendida en EE.UU. desde hace años: Crosby vs. Cuba Railroad Co. (1912), Walton vs. Arabian American Oil Company (1956), y fue también seguida en el pasado, en ciertos litigios, en Francia (regla Latour-Thinet), Suecia y Japón.

\section{b) La tesis de desestimación de la demanda y la tutela judicial efectiva}

67. La tesis de la «desestimación de la demanda» ha sido acusada de vulnerar el art. 24 CE y la «tutela judicial efectiva». Dicha acusación es total-

33 A. L. Calvo Caravaca / J. Carrascosa González, «Aplicación del Derecho extranjero en España y la nueva LEC», Tribunales de Justicia, nov. 2000, n. 11, pp. 1155-1170; ID., «Normas de conflicto, aplicación del Derecho extranjero en España y nueva LEC», Anuario Español DIP, núm. 1, 2001, pp. 215-237; ID., «El Derecho extranjero y el TS: la Sala de lo Social contraataca», Anuario Español DIP, 2002, pp. 103-114; ID., Derecho internacional privado, volumen I, 5. ${ }^{\text {a }}$ ed. Comares, Granada, 2004, p. 277; ID., «La prueba del derecho extranjero en la nueva Ley española de Enjuiciamiento Civil 1/2000», La Ley, 2005, núm. 6178 de 28 enero 2005, pp. 1-7; ID., «The Proof of Foreign Law in the New Spanish Civil Procedure Code 1/2000», IPRax, 2005-2, pp. 170 ss.

${ }^{34}$ P. Abarca Junco / M. Gómez Jene, «Alegación y prueba del Derecho extranjero en el procedimiento laboral», Rev. Esp. Der. Trabajo, sept.-oct. 2003, núm.119, pp. 713-737. 
mente infundada e injusta. En efecto: una sentencia que indica que la demanda o la pretensión jurídica debe ser «desestimada» constituye, sin duda ninguna, una «respuesta de fondo» al litigio (exigencia derivada del art. $24 \mathrm{CE}$ ). «Denegar la pretensión» es un modo plenamente correcto de «responder sobre el fondo», de «resolver el litigio» en Derecho. Optar por la «desestimación de la demanda» es una «respuesta de fondo» que respeta la «tutela judicial efectiva». Y aún hay más: es absolutamente necesario optar por la desestimación de la demanda cuando ésta no ha sido correctamente fundada, es decir, cuando los fundamentos jurídicos de la demanda son equivocados. Y cuando una parte alega y funda su demanda en el Derecho español cuando es claro, evidente, aceptado e indiscutido que el litigio se rige por un Derecho extranjero, dicha parte ha fundamentado incorrectamente su demanda: el tribunal está obligado a desestimar su pretensión porque ésta no ha sido correctamente argumentada desde un punto de vista jurídico. En tal caso, la «desestimación de la demanda» es una solución en perfecta «sintonía constitucional»: es una respuesta motivada y razonada, no arbitraria, y fundada en Derecho, y precisamente por ello, es una respuesta que satisface la «tutela judicial efectiva». Estos aspectos han sido tratados con todo rigor y gran brillantez por L. CARRILLO Pozo. Este autor indica, con pleno acierto, que esta tesis «resulta impecable bajo el prisma de la constitucionali$d a d »^{35}$, porque si la parte ha planteado incorrectamente su pretensión, no puede esperar que, en tal caso, el tribunal dicte «una sentencia que le dé la razón $»^{36}$. Por otro lado, la necesidad de fundar la pretensión en un Derecho extranjero no constituye ningún «presupuesto procesal» ni ningún «presupuesto de la acción». Fundar la pretensión en un Derecho extranjero cuando tal Derecho extranjero es el Derecho que objetivamente rige la controversia, es sólo «condición necesaria» para poder obtener una sentencia favorable. En los casos regidos por un Derecho extranjero, una pretensión no construida sobre tal Derecho extranjero conduce irremediablemente a la desestimación de la pretensión. E igualmente la falta de prueba de la legislación extranjera aplicable al fondo de litigio impide pronunciarse a los tribunales españoles y conduce inexorablemente a la desestimación de la pretensión.

El ATC 422/2004 de 4 noviembre 2004 bendice la constitucionalidad de la tesis de la desestimación de la demanda y deja muy clara su plena, total y perfecta sintonía con la «tutela judicial efectiva». Resulta útil y necesario recordar el caso que dio lugar al ATC 422/2004 de 4 noviembre 2004: el

${ }^{35}$ L. CARrillo Pozo, «Alegación y prueba del Derecho extranjero en el ámbito laboral y tutela judicial efectiva», Rev. Esp. Dcho. Trabajo, núm. 111, mayo-junio 2002, pp. 451473, esp. p. 455.

${ }^{36}$ L. CARrillo Pozo, «Alegación y prueba del Derecho extranjero en el ámbito laboral y tutela judicial efectiva», Rev. Esp. Dcho. Trabajo, núm. 111, mayo-junio 2002, pp. 451473, esp. p. 471. 
demandante, de nacionalidad italiana, trabajó para la Embajada de España en Turquía desde 1952 como auxiliar, oficial, Vicecanciller y Canciller, hasta que dejó de prestar sus servicios al cumplir los setenta años. Fue entonces cuando reclamó su derecho a percibir una pensión de jubilación de la Seguridad Social española. El Derecho turco regía la cuestión como Ley del país de prestación habitual de los servicios. Pues bien, el Derecho turco no fue alegado ni probado por el demandante. Por ello, las sentencias de instancia desestimaron la pretensión y no aplicaron el Derecho español como «sustituto de la Ley extranjera» (Ley turca). El demandante, que pretendía la aplicación de la Ley sustantiva española ante la falta de prueba de la Ley turca, interpuso recurso de amparo ante el TC por presunta vulneración de la tutela judicial efectiva (art. $24 \mathrm{CE}$ ). Pues bien: el TC indica, con apoyo en el Ministerio Fiscal, que la desestimación de la demanda, solución acordada por los tribunales ordinarios, fue una respuesta constitucionalmente impecable: «aplicando la anterior doctrina al caso de autos, resulta inadmisible la lesión del derecho a la tutela judicial efectiva (art. 24.1 CE) alegado, toda vez que las resoluciones recurridas contienen un razonamiento que constituye, lógica y jurídicamente, suficiente motivación de la decisión adoptada, al permitir conocer que su ratio decidendi ha sido la falta de acreditación por la parte demandante del contenido de la legislación extranjera, aplicable al caso conforme al art. 10.6 Cc. por ser el lugar de la prestación de servicios del demandante, y en la que, además, se había fundado jurídicamente la pretensión esgrimida. Tal y como mantiene el Ministerio Fiscal, el rechazo de las resoluciones judiciales discutidas a aplicar la legislación española ante la falta de prueba por el demandante del Derecho extranjero, no constituye una denegación injustificada del derecho a la tutela judicial efectiva, sino una aplicación razonada y razonable de la legalidad ordinaria aplicable al caso. De modo que la simple disconformidad del recurrente con el razonamiento judicial, con su corrección o acierto, o el hecho de que la decisión a la que el mismo conduzca sea contraria a las pretensiones del recurrente, no implica lesión alguna del derecho fundamental que protege el art. 24.1 CE, ni, como tantas veces se ha dicho, permite a este Tribunal su revisión cual si de una nueva y superior instancia judicial se tratase (por todas, entre las más recientes, STC 76/2004, de 26 de abril de 2004 F. 3) .... No cabe, por tanto, apreciar la lesión del derecho a la igualdad ante la Ley, al constituir su queja, también en este caso, una mera disconformidad con la decisión judicial, razonada y razonable, de no aplicar subsidiariamente la legislación laboral española ante la falta de prueba del Derecho extranjero».

c) La tesis de la desestimación de la demanda y el art. 218.1.II LEC.

68. La incidencia del art. 218.1.II LEC en la alegación y prueba del Derecho extranjero es crucial. El texto de esta disposición indica que «[e]l tribunal, sin apartarse de la causa de pedir acudiendo a fundamentos de 
hecho o de Derecho distintos de los que las partes hayan querido hacer valer, resolverá conforme a las normas aplicables al caso, aunque no hayan sido acertadamente citadas o alegadas por los litigantes». Como explica I. TAPIA FERNÁNDEZ ${ }^{37}$, el tribunal no puede, a la hora de dictar sentencia, apartarse de la «causa de pedir» o causa petendi. En la LEC 1/2000, la «causa de pedir» está compuesta por dos elementos: a) el «elemento fáctico» (los «hechos»); b) el «elemento jurídico (los «fundamentos de derecho» realizados por los litigantes). La doctrina entiende que el «elemento jurídico» de la causa de pedir está compuesto, a su vez, por dos «factores»: a) el «fundamento jurídico de la pretensión» (es el «razonamiento jurídico» realizado por la parte); b) la «fundamentación jurídica» esgrimida por el litigante (el «soporte normativo» o conjunto de concretas normas jurídicas que, en opinión del litigante, son aplicables al caso y que apoyan su «razonamiento jurídico»). El tribunal está vinculado, sin duda, por el «fundamento jurídico de la pretensión» (por el «razonamiento jurídico») esgrimido por el actor. Si éste comete un error y esgrime un «fundamento jurídico» o «razonamiento jurídico» incorrecto, el tribunal no puede ni debe remediar dicho error. El tribunal está obligado, en tal caso, a dictar sentencia desestimatoria de la pretensión. El tribunal ni puede ni debe «corregir» a las partes si éstas aciertan en el «fundamento jurídico de la pretensión» pero se equivocan totalmente en lo que respecta al «soporte normativo» de tal fundamento. Por supuesto, tampoco el tribunal puede ni debe «corregir» a las partes si el «fundamento jurídico» de la pretensión es incorrecto y el «soporte jurídico» esgrimido también es incorrecto. El lugar que el principio jura novit curia ocupa en esta segunda tesis es diferente: el tribunal puede y debe corregir meros «errores materiales de las partes», tales como haber citado incorrectamente el tenor literal de un precepto, haber alegado un precepto cuando resulta claro que se quería alegar otro, cuando se cita un principio general del Derecho con un nombre equivocado, cuando se alegan normas de pertinente aplicación junto con normas inaplicables al caso, todas juntas y revueltas, siempre que se pueda extraer el «soporte jurídico principal» en el que se basa la parte, etc. El poder del tribunal para corregir «errores meramente materiales» cometidos por las partes se extrae de la letra del art. 218.1.II LEC, que sólo autoriza la intervención del tribunal cuando las partes han alegado las correctas «normas aplicables al caso», pero no lo han hecho «acertadamente». Es decir, no citar o alegar «acertadamente» las normas aplicables significa que se han citado y alegado las normas verdaderamente aplicables al supuesto, pero ello no se ha hecho «con exhaustividad y completa precisión» (A. DE la Oliva SANTOS / I. DíeZ-PiCAZo GimÉNEZ ${ }^{38}$ ).

${ }^{37}$ I. TAPIA FernándEZ, El objeto del proceso. Alegaciones, sentencia cosa juzgada, Ed. La Ley, Madrid, 2000, pp. 116-118.

38 A. De la Oliva Santos / I. Díez-Picazo Giménez, Derecho procesal civil. El proceso de declaración, 3. a ed., Ed. Univ. Ramón Areces, Madrid, 2004, p. 459. 
Este es el alcance justo y cabal del principio jura novit curia: el Derecho español no debe ser probado por las partes ni por el tribunal y el tribunal debe aplicar el Derecho objetivamente aplicable al supuesto, pero sin apartarse de la «causa de pedir» esgrimida por las partes. Por tanto, el tribunal no puede «sustituir la norma o conjunto de normas positivas en que, por lo que el litigante ha expuesto y pedido, se basa explícita o implícitamente la pretensión de obtener una concreta tutela jurisdiccional, por norma o normas distintas, no alegadas por ninguna de las partes» (A. DE LA OLIVA SANTOS / I. DíEZ-PicAzo GimÉNEZ ${ }^{39}$ ). Por ello, se equivocan gravemente los autores, como A. EsPINIElla MENÉNDEZ, que afirman que «las normas jurídicas no aportan nada a la identificación del objeto procesal» y que «el cambio de la ley aplicable no altera la causa» ${ }^{40}$. Naturalmente que un cambio de la ley aplicable supone un cambio radical en la causa petendi. Basta comprender, como explica la doctrina procesalista citada, que el «elemento jurídico (los «fundamentos de derecho» realizados por los litigantes) de la causa petendi está compuesto por dos factores: el «razonamiento jurídico» realizado por las partes y el «soporte normativo» o conjunto de concretas normas jurídicas en las que las partes se apoyan. Es evidente que si se cambia el «soporte normativo» esgrimido a través de un cambio de Ley aplicable, la causa petendi cambia. Sostener lo contrario denota carencias jurídicas preocupantes.

69. La proyección del art. 218.1.II LEC en los litigios regidos por un Derecho extranjero produce consecuencias poderosas e interesantes.

Primera consecuencia. Si una parte fundamenta jurídicamente su pretensión en el Derecho sustantivo español y no en el Derecho extranjero que debe, según las normas de conflicto españolas, regir el supuesto, el art. 218.1.II LEC entra en acción. En la inmensa mayoría de estos casos, el «fundamento jurídico» será equivocado y el «soporte jurídico» alegado será erróneo. Por tanto, el tribunal español debe desestimar su pretensión. Equivocarse en el «Derecho estatal aplicable» al supuesto no es un mero «error material» que el tribunal puede o debe «corregir» en virtud del principio jura novit curia. Un error flagrante en el «razonamiento jurídico» y en el «soporte jurídico» conduce inexorablemente a la desestimación de la pretensión. O en las palabras utilizadas por L. CARRILlo Pozo, cuando un pleito se rige por un Derecho extranjero, «la alegación del Derecho extranjero aplicable según la norma de conflicto española es imperativa, condición para la acogida de las pretensiones del demandante» y además, «sin alega-

${ }^{39}$ A. De la Oliva Santos / I. DíEz-Picazo Giménez, Derecho procesal civil. El proceso de declaración, 3. a ed., Ed. Univ. Ramón Areces, Madrid, 2004, pp. 456-459, esp, p. 459.

${ }^{40}$ A. Espiniella MenÉndeZ, «Nota a STC, Sala Segunda, núm. 172/2004, de 18 de octubre», en REDI, 2005-I, vol. 57, pp. 344-349. 
ción del Derecho extranjero aplicable las pretensiones del demandante se desestimarán siempre» ${ }^{41}$.

Segunda consecuencia. Los supuestos en los que el «razonamiento jurídico» sea «correcto» y el «soporte jurídico» sea «incorrecto» (porque la pretensión se fundamentó en Derecho español cuando debía haberse fundamentado en un Derecho extranjero) son rarísimos. En la práctica puede decirse que estos casos serán inexistentes. En efecto: para que el «razonamiento jurídico» sea correcto, éste tendría que ser la consecuencia jurídica que el Derecho extranjero, aplicable al caso, anuda a unos determinados hechos, lo que no se producirá si se fundamenta la pretensión en el Derecho español cuando es aplicable el Derecho extranjero. Además, si la parte fundamenta su pretensión en el Derecho español es porque sabe que el Derecho extranjero no ampara su «fundamento jurídico». Pero incluso aun cuando se produjera este extrañísimo supuesto («razonamiento jurídico» correcto, pero «soporte jurídico» incorrecto), lo más ajustado a la letra y espíritu del art. 218.1.II LEC es desestimar la pretensión. El principio jura novit curia no debe activarse en estos casos, porque equivocarse en el «Derecho estatal aplicable» no es un «mero error material» padecido por la parte, de modo que el tribunal no debe ni puede «corregirlo».

Tercera consecuencia. Con la desestimación de la demanda se evita beneficiar a partes y abogados que no realizan correctamente su trabajo (el abogado redacta una demanda horrenda: no puede esperar que el tribunal haga valer argumentos jurídicos y preceptos legales que el mismo abogado no ha sabido ni ha querido introducir en el proceso), se protege la imperatividad de la norma de conflicto (evitando el zapping legal al que ciertos individuos son tan aficionados, de modo que un pleito regido por un Derecho extranjero nunca será resuelto con arreglo al Derecho español) y se salvaguarda la tutela judicial efectiva de la otra parte (que sólo estará obligada a defenderse contra los «soportes jurídicos» que han sido efectivamente esgrimidos contra ella por la parte contraria, pues el tribunal debe operar en el marco de los términos del debate procesal suscitado por las partes).

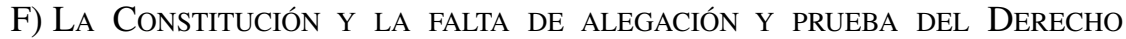 EXTRANJERO}

70. La Constitución española no contiene ninguna regla, norma o principio que indique cuál es la solución jurídica al caso en el que un Derecho extranjero que rige el fondo del asunto, no ha sido alegado y probado por las

${ }^{41}$ L. CARrillo Pozo, «Alegación y prueba del Derecho extranjero en el ámbito laboral y tutela judicial efectiva», Rev. Esp. Dcho. Trabajo, núm. 111, mayo-junio 2002, pp. 451473, esp. p. 473; ID., «Una doctrina constitucional sobre alegación y prueba de la Ley extranjera», Ar. Social, 2003, núms.7-8, pp. 53-84. 
partes. Ni expresa ni implícita (L. CARRILlo PozO ${ }^{42}$ ). La Constitución española sí contiene, por supuesto, determinados preceptos que presentan un «alcance general» para todo el Derecho privado, lo que engloba, naturalmente, al Derecho internacional privado, que como es sabido, es Derecho privado. Entre tales principios, algunos pueden ser utilizados para averiguar qué tesis de entre las tesis antes vertidas supera el «test de ajuste constitucional». En concreto, el principio de «seguridad jurídica», la «interdicción de la arbitrariedad de los poderes públicos» y el derecho a la «tutela judicial efectiva» conforman los «parámetros constitucionales relevantes» para dilucidar la adecuación constitucional de las tesis en conflicto.

71. Haciendo escala en el derecho a la «tutela judicial efectiva», de tal derecho deriva la exigencia siguiente: toda persona tiene derecho a una «respuesta de fondo», razonada en Derecho, sobre su pretensión ejercitada ante los tribunales españoles. Por tanto, la tesis que se prefiera sobre la cuestión de qué hacer ante un caso en el que el demandante funda su pretensión en el Derecho español cuando el caso debe regularse por un Derecho extranjero, debe satisfacer las exigencias derivadas del derecho de «tutela judicial efectiva» recogido en el art. $24 \mathrm{CE}$. Cualquier solución que se ofrezca a la cuestión debatida debe estar, en todo caso, jurídicamente fundada, motivada y ser razonable y «no arbitraria» (STC 10/2000, de 17 de enero de 2000). Pero el derecho fundamental a la tutela judicial efectiva no implica el derecho de la parte a obtener un «pronunciamiento acorde con las pretensiones de la parte», sino el derecho a obtener «una resolución fundada en Derecho» (STC 55/1993, de 15 de febrero 1993, ATC 148/1999, de 14 de junio 1999, STC 10/2000, de 17 de enero de 2000, STC 1/1996, de 15 de enero 1996, STC 217/1998, de 16 de noviembre 1998, STC 183/1999, de 11 de octubre 1999).

72. Pues bien: examinadas detenidamente, la tesis de la «aplicación sustitutiva del Derecho sustantivo español», la tesis de la «aplicación de oficio del Derecho extranjero» y la tesis de la «desestimación de la demanda» cumplen, las tres, con el derecho a la «tutela judicial efectiva». Las tres tesis proporcionan una respuesta «fundada en Derecho» a los casos en los que el Derecho extranjero aplicable al litigio no ha sido alegado ni probado. Las tres tesis superan el «test de ajuste constitucional». Por tanto, resulta que el debate entre las tres tesis antes citadas y la preferencia por una de las tres tesis en conflicto son cuestiones situadas «más allá del ajuste constitucional» (no «al margen del ajuste constitucional»). En otras palabras: visto que las tres tesis encajan con el art. $24 \mathrm{CE}$ (el ajuste constitucional es necesario

${ }^{42}$ L. CARrillo Pozo, «Alegación y prueba del Derecho extranjero en el ámbito laboral y tutela judicial efectiva», Rev. Esp. Dcho. Trabajo, núm. 111, mayo-junio 2002, pp. 451473, esp. p. 465; ID., «Una doctrina constitucional sobre alegación y prueba de la Ley extranjera», Ar. Social, 2003, núms.7-8, pp. 53-84. 
siempre, pero se cumple en relación con las tres tesis enfrentadas), la preferencia por una de las tres tesis resulta ser una cuestión de «legalidad ordinaria» (L. CARRILlo POZO ${ }^{43}$ ). Es, así, el legislador, y en su caso, también los tribunales, los que tienen que decidir qué tesis es preferible. En consecuencia, el TC nada tiene que decir sobre el tema. Y si el TC se pronuncia al respecto - cosa que no ha hecho, pese a lo que erróneamente sostienen algunos autores y ciertas sentencias-, ello no vinculará a los tribunales, porque en tal caso, el TC no está operando como «intérprete supremo de la Constitución» (Voto particular a STS, Social, 4 noviembre 2004).

73. Y a todo esto, ¿qué ha afirmado el TC sobre la cuestión? En general, cabe afirmar que el TC se mueve con enorme dificultad ante este problema clave para el Derecho internacional privado: el TC no maneja con claridad las relaciones peligrosas entre «prueba del Derecho extranjero» y «tutela judicial efectiva $»^{44}$. Varios pronunciamientos del TC han abordado el problema. Entre ellos, los más destacables son los siguientes: a) STC 10/2000 de 17 enero 2000; b) STC 155/2001 de 2 julio 2001; c) STC 33/2002 de 11 febrero 2002; d) STC 172/2004 de 18 octubre 2004.

En la STC 10/2000 de 17 enero 2000, el TC indicó, únicamente, que cuando una parte intenta probar con todos sus recursos y medios a su alcance el Derecho extranjero y no le es ello posible, el tribunal debe ayudar a probar tal Derecho mediante los mecanismos jurídicos de los que disponen los órganos jurisdiccionales, que suelen ser más extensos y eficaces de los que disponen las partes. Pero sobre la cuestión de «qué Derecho debe aplicarse en el supuesto de que el Derecho extranjero aplicable al fondo del asunto no sea probado», el TC no indica nada en absoluto desde una «perspectiva constitucional».

En la STC 155/2001 de 2 julio 2001, el TC indicó que cuando es aplicable un Derecho extranjero y éste no se prueba por la parte, si el tribunal desestima la demanda, debe fundamentar o justificar dicha decisión para cumplir

${ }^{43}$ L. CARrillo Pozo, «Alegación y prueba del Derecho extranjero en el ámbito laboral y tutela judicial efectiva», Rev. Esp. Dcho. Trabajo, núm. 111, mayo-junio 2002, pp. 451473, esp. p. 465; ID., «Una doctrina constitucional sobre alegación y prueba de la Ley extranjera», Ar. Social, 2003, núms.7-8, pp. 53-84.

${ }^{44}$ L. CARBALlo PIÑEIRO, «El carácter imperativo de la norma de conflicto y la prueba del Derecho extranjero: Una relectura en clave procesal y constitucional», AEDIP, núm. 1, 2001, pp. 483-503; L. CARRILlo Pozo, «Alegación y prueba del Derecho extranjero en el ámbito laboral y tutela judicial efectiva», Rev. Esp. Dcho. Trabajo, núm. 111, mayo-junio 2002, pp. 451-473; ID., «Una doctrina constitucional sobre alegación y prueba de la Ley extranjera», Ar. Social, 2003, núms.7-8, pp. 53-84; V. CuARTERo Rubio, «Prueba del Derecho extranjero y tutela judicial efectiva», Derecho Privado y Constitución, n. 14, 2000, pp. 21-71; J. MASEDA RODRÍGUEZ, «La aplicación judicial del Derecho extranjero: el nuevo régimen de la LEC y la reciente jurisprudencia del Tribunal Constitucional», Actualidad Civil, n. 12, 2002, pp. 413-446. 
con el principio de «tutela judicial efectiva» (arts. 24 y 120.3 CE). A pesar de las apariencias, que como es frecuente, engañan y mucho, el TC nada indica sobre la cuestión de «qué concreto Derecho debe aplicarse en el supuesto de que el Derecho extranjero aplicable al fondo del asunto no sea probado». El TC sólo precisa que si se opta por «desestimar la demanda», tal solución jurídica debe «fundarse en Derecho», razonarse, motivarse, y además, visto que el TS mantiene una determinada postura sobre la cuestión en una copiosa y centenaria jurisprudencia (aplicación sustitutiva del Derecho español), si el tribunal opta por otra solución (desestimación de la demanda), ello debe justificarse con un «plus de motivación» (del que, por cierto, el TC no señala en qué consiste y qué grado de profundidad debe presentar). La «simple desestimación» (desestimación «no motivada»o «no razonada» o «no justificada jurídicamente») no es constitucionalmente aceptable como respuesta al problema de «cuál es la respuesta jurídica en caso de falta de alegación y prueba del Derecho extranjero».

En la STC 33/2002 de 11 febrero 2002, el TC declaró que no se puede «inadmitir la demanda» ni dejar de pronunciarse sobre el fondo cuando la parte demandante debe fundar dicha demanda en un Derecho extranjero y no lo hace. Sobre la cuestión de «qué Derecho concreto debe aplicarse en el supuesto de que el Derecho extranjero aplicable al fondo del asunto no sea alegado ni probado», el TC no indica nada. Debe recordarse que la sentencia fue objeto de un «voto particular», de calidad muy notable, en el que el magistrado disidente, Excmo. Sr. D. Vicente Conde Martín de Hijas, insiste en que la solución al problema de cuál es la postura jurídica a adoptar en caso de que el Derecho extranjero no sea alegado ni probado es una cuestión de mera «legalidad ordinaria», sobre la que el TC puede expresar lo que tenga por conveniente, pero sin que ello pueda ser estimado como «doctrina constitucional del TC» que vincule a todos los órganos jurisdiccionales españoles. Posición que se ha visto refrendada por el importantísimo Auto TC 422/2004 de 4 noviembre 2004: «el rechazo de las resoluciones judiciales discutidas a aplicar la legislación española ante la falta de prueba por el demandante del Derecho extranjero, no constituye una denegación injustificada del derecho a la tutela judicial efectiva, sino una aplicación razonada y razonable de la legalidad ordinaria aplicable al caso. De modo que la simple disconformidad del recurrente con el razonamiento judicial, con su corrección o acierto, o el hecho de que la decisión a la que el mismo conduzca sea contraria a las pretensiones del recurrente, no implica lesión alguna del derecho fundamental que protege el art. 24.1 CE, ni, como tantas veces se ha dicho, permite a este Tribunal su revisión cual si de una nueva y superior instancia judicial se tratase».

En la STC 172/2004, de 18 de octubre de 2004, el TC acredita que lo aducido por el demandante de amparo no fue realmente así, sino que los Juzgados y tribunales españoles del orden de lo Social que decidieron el caso en distintas instancias siempre aplicaron el Derecho uruguayo. Por tanto, ni 
«desestimaron la demanda», ni «aplicaron subsidiariamente el Derecho sustantivo español». Y nada indica el TC sobre la cuestión de cuál es la respuesta jurídica que debe ofrecerse en el caso de que el Derecho extranjero aplicable al caso concreto no se haya alegado ni probado.

En el ATC 422/2004 de 4 noviembre 2004, el TC deja claro que la Constitución no impone una determinada tesis para dar solución al problema y que muy especialmente la tesis de la «desestimación de la demanda» puede utilizarse por los tribunales españoles, siempre que el tribunal motive y razone su decisión.

Por tanto, el TC no ha tomado partido por la tesis de la «aplicación sustitutiva del Derecho material español», pese a lo afirmado erróneamente por ciertos autores. El TC ha rechazado sólo una de las tesis en conflicto: la tesis de la «inadmisión de la demanda» no es constitucionalmente ajustada. El $\mathrm{TC}$, finalmente, no ha tomado partido por ninguna de las tesis que se han propuesto.

Para cerrar este debate debe recordarse que la decisión de cuál de las tesis vertidas sobre el problema de la falta de alegación y prueba del Derecho extranjero por las partes es una decisión situada «más allá del debate constitucional»: es una cuestión de «legalidad ordinaria». Así lo dice expresamente el muy relevante ATC 422/2004 de 4 noviembre 2004: "el rechazo de las resoluciones judiciales discutidas a aplicar la legislación española ante la falta de prueba por el demandante del Derecho extranjero, no constituye una denegación injustificada del derecho a la tutela judicial efectiva, sino una aplicación razonada y razonable de la legalidad ordinaria aplicable al caso. De modo que la simple disconformidad del recurrente con el razonamiento judicial, con su corrección o acierto, o el hecho de que la decisión a la que el mismo conduzca sea contraria a las pretensiones del recurrente, no implica lesión alguna del derecho fundamental que protege el art. 24.1 CE, ni, como tantas veces se ha dicho, permite a este Tribunal su revisión cual si de una nueva y superior instancia judicial se tratase».

\section{Prueba imposible del Derecho extranjero}

74. En ciertos casos la prueba del Derecho extranjero puede resultar imposible: países de reciente creación, países en guerra, información insuficiente, etc. En dichos supuestos, el art. 281.2 LEC guarda silencio. Deben diferenciarse dos hipótesis.

Primera. Algunos preceptos del Derecho extranjero se han probado adecuadamente, pero otros preceptos no han sido probados, y resulta muy dificultoso recabar una información más profunda. En tal caso, los preceptos del Derecho extranjero que se hayan probado con éxito, se aplicarán. Los aspectos regidos por un Derecho extranjero cuya prueba ha resultado imposible se regirán por el Derecho designado por el siguiente punto de conexión de la norma de conflicto, si existe, y en última instancia, se regirán por el Derecho 
material español. Así operó la SAP Navarra 29 diciembre 2004: se solicitó prueba del Derecho suizo sobre seguros a través del antes citado Convenio de Londres de 1968, pero las autoridades suizas suministraron una prueba incompleta del mismo. El tribunal navarro aplicó todo el Derecho suizo que había sido probado, y en la parte que no se consiguió probar, aplicó el Derecho material español (SAP Navarra 29 diciembre 2004).

Segunda. En casos de prueba imposible total del Derecho extranjero, dos soluciones son posibles: a) se puede presumir la voluntad del legislador de, en tal caso, acudir al Derecho designado por el siguiente punto de conexión de la norma de conflicto, si existe (SAP Madrid 28 septiembre 2000); b) si la norma de conflicto sólo dispone de un único punto de conexión, se aplicará el Derecho material español como ultima ratio. Otras soluciones, apuntadas por la doctrina, no parecen adecuadas: rechazar la demanda, aplicar el Derecho que más se aproxime al Derecho extranjero inaplicable (Mutterrecht), aplicar un «Derecho uniforme» (Ersatzrecht) surgido de una síntesis entre los ordenamientos jurídicos en presencia o la «resolución judicial» del caso. 